\title{
The Death of Rabbi Eliezer: Bavli Sanhedrin 68a
}

\author{
Jeffrey L. Rubenstein
}

It is most fitting that a volume in honor of Rabbi Joel Roth includes the study of a story about masters and disciples. Rabbi Roth has been the consummate teacher and rabbinic master at the Jewish Theological Seminary for decades. He taught me Talmud during my first year of study at JTs, and it is from Rabbi Roth that I learned many of the skills necessary for scholarship of rabbinic literature. To be counted among his disciples is a great honor.

The story of the death of R. Eliezer b. Hyrcanos in b. Sanh. 68a provides an instructive case of the literary artistry, cultural world, and compositional techniques of the late Bavli storytellers. The content addresses a tension between the merit of Torah and the punishment due to dissidents, and also grapples with issues of master-disciple relationships and the transmission of tradition through the generations. Comparison with an earlier version of the account in y. Šabb. 2:5, 5 b provides a fascinating example of the methods of the Bavli's reworking of earlier sources to create new narratives. The story has received considerable scholarly attention: apart from the older biographical-historical oriented scholarship, there are detailed literary analyses by Alon GoshenGottstein $^{1}$ and Devora Steinmetz, ${ }^{2}$ and studies by Yonah Fraenkel, Daniel Boyarin, Ruth Calderon, Shamma Friedman, Joshua Levinson, and others. ${ }^{3}$ Jacob

1 Alon Goshen-Gottstein, "A Lonely Sage on His Death-Bed: The Story of Rabbi Eli'ezer (Sanhedrin 68a), an Ideological Analysis" [in Hebrew], in Mehkarim batalmud uvamidrash: Sefer zikkaron letirzah lifshitz, ed. Moshe Bar-Asher, Joshua Levinson, and Berachyahu Lifshitz (Jerusalem: Bialik, 2005), 79-112.

2 Devora Steinmetz, "'Like Torah Scrolls That Are Rolled Up': The Story of the Death of Rabbi Eliezer in Sanhedrin 68a," in Tiferet Leyisrael: Jubilee Volume in Honor of Israel Francus, ed. J. Roth, M. Schmelzer, and Y. Francus (New York: Jewish Theological Seminary, 2010), 153-179.

3 Yonah Fraenkel, "Time and Its Shaping in Aggadic Narratives" [in Hebrew], in Studies in Aggadah, Targum and Jewish Liturgy in Memory of Joseph Heinemann, ed. J.J. Petuchowski and E. Fleischer (Jerusalem: Magnes, 1981), 147-152; Daniel Boyarin, Border Lines: The Partition of Judaeo-Christianity (Philadelphia: University of Pennsylvania Press, 2004), 171-180; idem, Dying for God (Stanford: Stanford University Press, 1999), 36-41; Ruth Calderon, "Literary Tropes in the Aggadic Narratives of the Babylonian Talmud" [in Hebrew] (Ph.D. diss., Hebrew University, 2006), 135-149; Joshua Levinson, "Enchanting Rabbis: Contest Narratives between Rabbis and Magicians in Late Antiquity, JQR 100 (2010): 54-94; Shamma Friedman, 
Neusner's biographical work and Yitshaq Gilat's comprehensive study of R. Eliezer's halakhah are also helpful, especially regarding the halakhic elements of the story. ${ }^{4}$ All of this work has informed this study, although I make no attempt at comprehensive engagement with every scholarly study. My reading differs from these previous studies both in its general emphasis and on various interpretive points, and I also devote particular attention to the reworking of sources, dating, and Talmudic context. I begin with the literary analysis of the Bavli story and then proceed to a comparison with the Yerushalmi account in order to identify and assess the nature and sources of the Bavli's reworking. The last section considers the redactional context in Tractate Sanhedrin. The text and translation are based on Ms Munich 95 with variants noted in the appendix.

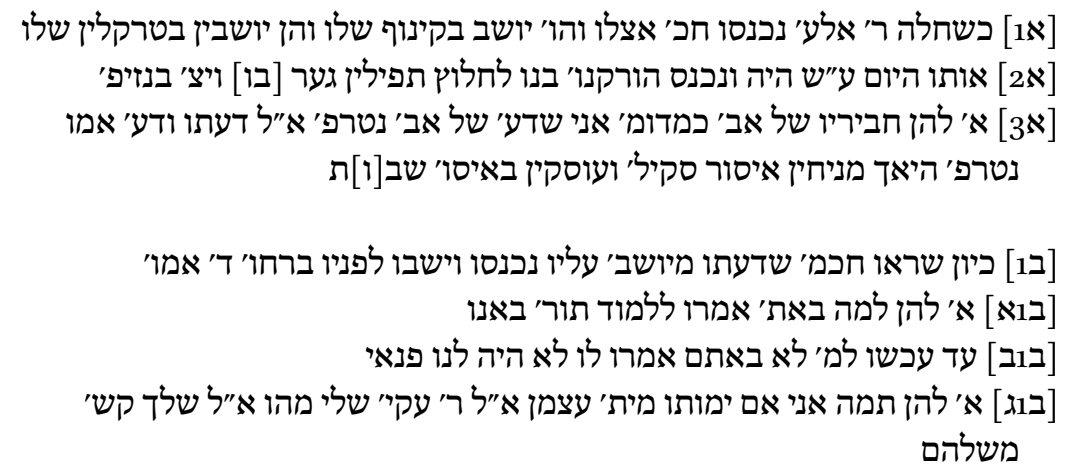

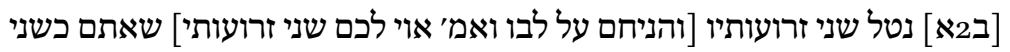

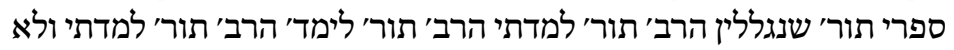

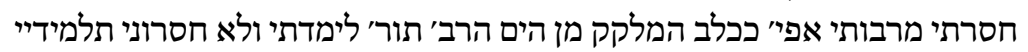
אפי' כמכחול בשפופר'

[ב2] ולא עוד אל' שאני שונ' שלש מאו' הלכו' בבהר' עזה ולא היה אד' ששאלני בהן דבר מעולי ולאוד ובאי

[בג'] ולא עו' אל' ששונ' אני שלש מאו' הלכות ואמרי לה שלש' [אלפים] הלכו' בנטיע' קישואין ולא היה אד' ששאלני בהן דב' מעול' חוץ מעקיב' בל יל יוסף פע' הלכו' אח'

"Now You See it, Now You Don't: Can Source-Criticism Perform Magic on Talmudic Passages about Sorcery?," in Rabbinic Traditions between Palestine and Babylonia, ed. R. Nikolsky and T. Ilan (Leiden: Brill, 2014), 43-61. For additional studies, see Inbar Raveh, Me'at meharbeh (Or Yehudah: Devir, 2008), 16o-166; Azaria Baitner, Yavneh Stories [in Hebrew] (Ramat Gan; Bar-Ilan University Press, 2011), 56-100.

4 Jacob Neusner, Eliezer ben Hyrcanus: The Tradition and the Man, 2 vols. (Leiden: Brill, 1973), 1:408-415; 2:222-223; Y. Gilat, R. Eliezer ben Hyrcanus: A Scholar Outcast, trans. E.J. Frank (Ramat Gan: Bar-Ilan University Press, 1984). 


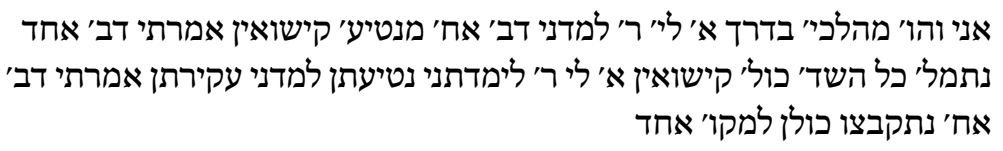

[בא"] אמרו לו ר' הכדור והאמון והקמיע וצרור המרגלי ומשקל' קטנ' מהו א' להן הן

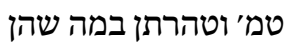

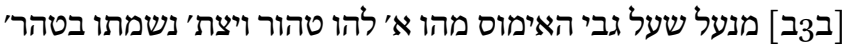

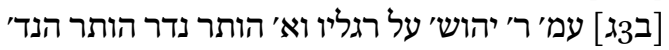

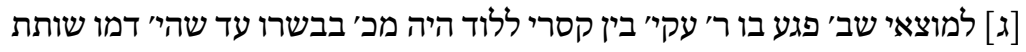

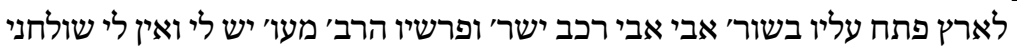
להרצותן

[A1] When R. Eliezer became sick, the Sages entered his [abode]. He was sitting on his canopied bed, and they were sitting in his receiving room.

[A2] That day was the eve of the Sabbath, and Hyrcanos, his son, entered to remove his tefillin. He [R. Eliezer] rebuked him [Hyrcanos] and he left in disgrace.

[A3] He [Hyrcanos] said to them, "Colleagues of my father. It seems that my father's mind is confused." He [R. Eliezer] said to him, "Your ${ }^{5}$ mind and your mother's mind are confused. How can one neglect a prohibition [punishable by] stoning, and busy oneself with a prohibition [that is merely a matter] of Sabbath rest [shevut]?"

[B1] When the Sages saw that his mind was lucid, they entered and sat before him at a distance of four cubits.

(a) He said to them, "Why have you come?" They said, "We have come to learn Torah."

(b) [He said to them,] "Why have you not come until now?" They said to him, "We had no free time."

(c) He said to them, "I will be amazed if you all ${ }^{6}$ die natural deaths." R. Akiba said to him, "What about my [death]?" He said to him, "Yours will be more severe than theirs."

5 Literally, "His mind and his mother's mind," using the third person for the second. Cf. the manuscript variants in the appendix.

6 Literally, "if they die," using the third person for the second. 
[B2]

(a) He took his two arms and placed them on his chest. He said, "Woe to you, my two arms, which are like two rolled Torah scrolls. I have learned a great amount of Torah and I have taught a great amount of Torah. I have learned a great amount of Torah — and I did not take away from my masters even as much as a dog laps up from the sea. I have taught a great amount of Torah-yet my students have not taken away from me even as much as a painting stick [takes out] of its tube.

(b) "Not only that, but I recite 300 laws about the bright spot ${ }^{7}$ and no one ever asked me a question about them.

(c) "Not only that, but I recite 300 laws - and some say 3000 lawsabout the planting of cucumbers, and no one ever asked me a question about them, except for Akiba b. Yosef: Once he and I were walking on our way, and he said to me, 'My master. Teach me one thing about the planting of cucumbers.' I said one thing, and the whole field filled up with cucumbers. He said to me, 'My master:You taught me about their planting. Teach me about their uprooting.' I said one thing and they all gathered in one place."

[B3]

(a) They [the Sages] said to him: "Master: A ball, a shoemaker's last, an amulet, a bag for pearls and a small weight—what is the law?" He said to them, "They are susceptible to impurity, and they are made pure [by immersion] as they are." ${ }^{8}$

(b) [They said to him,] "A shoe on the last—what is the law?" He said to them, "It is pure."

(c) And his soul departed with "Pure."10 R. Yehoshua stood on his feet and said, "The vow is annulled. The vow is annulled."

$7 \quad$ A potential sign of leprosy (nega'im). See Lev 13:4-56; m. Neg. 1:1.

8 That is, they may be immersed in their present state, without removing the inside filling; see n. 47 .

9 I.e., it is not susceptible to impurity, as it is not yet complete, hence it does not have the status of a vessel $(k e l i)$.

10 Or "his soul departed in purity." I prefer to take this as a reference to R. Eliezer's last word; see the analysis below. The phrasing probably derives from the end of Mishnah Kelim (m. Kelim 30:4): "Happy are you Kelim, that you entered in impurity and departed in purity." In the parallel use of this phrase in b. B. Mes. 86a, it is clear that the reference is to the last words of Rabbah bar Naḥmani. 
[C] After the Sabbath, R. Akiba encountered him [= R. Eliezer's funeral procession $]^{11}$ between Caeserea and Lod. He [Akiba] ${ }^{12}$ was striking his flesh until his blood gushed upon the earth. In the row [of mourners] he [Akiba] opened [his eulogy, and said]: "My father! My father! Israel's chariot and horsemen (2 Kgs 2:12). ${ }^{13}$ I have many coins and no moneychanger to sort them."

\section{Literary Analysis}

The story can be divided into three parts. ${ }^{14}$ In the first part, R. Eliezer's son Hyrcanos approaches his father when close to death. From their interchange, the Sages learn that R. Eliezer is in command of his faculties and therefore can be engaged in serious discussion. The second part narrates that discussion, which culminates in the annulment of the ban. In the third part R. Akiba expresses his grief and pronounces a eulogy.

The second and longest part, the heart of the story, itself exhibits a tripartite structure $\left(\mathrm{B}_{1}, \mathrm{~B}_{2}, \mathrm{~B}_{3}\right)$, each third of which can be further subdivided into three sections. In the first third R. Eliezer interrogates the Sages with two questions ( $\mathrm{Bra}, \mathrm{Brb})$ and then makes a pronouncement relating to their deaths (B1c). In the second third R. Eliezer makes three laments (B2a, B2b, B2c). In the final third the Sages interrogate Eliezer with two questions (B3a, $\left.\mathrm{B}_{3} \mathrm{~b}\right)$, and then R. Yehoshua makes a pronouncement related to his death $\left(\mathrm{B}_{3} \mathrm{C}\right)$. Thus the first and third sections of this part reverse the direction of the questioning while corresponding almost perfectly in their pattern, two questions and a pronouncement. ${ }^{15}$

11 The identities of the subject and object of this line are difficult to determine. One could interpret that R. Akiba encountered R. Yehoshua between Caeserea and Lod, and that R. Yehoshua was striking his flesh and then pronounced the eulogy. In the PT R. Yehoshua indeed articulates the eulogy, but since R. Akiba appears nowhere in the PT, it is questionable whether that version should influence our understanding of the Bavli (see below). In light of R. Akiba's prominent role in the narrative, I take him to be the subject here.

12 See the previous note.

13 This phrase also appears in 2 Kgs 13:14.

14 Cf. the five part chiastic structure in Goshen-Gottstein, "Lonely Sage," 81-82. In fact our structures are quite similar, as he considers $\mathrm{my} \mathrm{B}_{1}, \mathrm{~B}_{2}$ and $\mathrm{B}_{3}$ as independent units, resulting in the same five divisions $\left(\mathrm{A}, \mathrm{B} 1, \mathrm{~B}_{2}, \mathrm{~B}_{3}, \mathrm{C}\right)$.

15 I say "almost" because section Bic actually contains two statements of R. Eliezer, while B3C contains the narrated datum that his soul departed prior to R. Yehoshua's statement. So the structure is not perfectly symmetrical, but close enough, in my opinion, to facilitate memorization and highlight the relationship between the parts, which I believe are the 
Shifts in time, the changing location of the Sages, and changes in the status of R. Eliezer contribute to the tripartite structure. The first part takes place at "the eve of the Sabbath," at dusk. The third part takes place "after the Sabbath." It is not stated exactly when the second part takes place. Since it comes after the first part, it is reasonable to assume that it takes place once the Sabbath has begun, i.e., on the Sabbath. In the first part the Sages wait in R. Eliezer's receiving room. In the second part they enter his bedroom. In the third part they-or at least R. Akiba-come upon R. Eliezer's funeral procession between Caeserea and Lod. ${ }^{16}$ In the first part R. Eliezer is sick, but alive. The second part narrates his death. The third part takes place after his death. Thus the story exhibits a finely crafted tripartite structure, as is characteristic of many other Bavli stories.

This story may be designated a "deathbed scene" a loose narrative type attested several other times in the Bavli (with more examples in other rabbinic documents), in which the dying sage bids his final farewell to his disciples. In an attempt to emulate similar studies of such scenes in Christian Scriptures and to define a narrative form, Anthony Saldarini collected these sources and listed "ten identifiable elements." ${ }^{17}$ But no story has all the elements, and some are missing so many that hypothesizing such a form yields an analytical tool of limited utility. Nevertheless, we do gain a sense of the variety of deathbed scenes by which to compare and contrast our story. The Bavli, in fact, preserves a more typical deathbed story of R. Eliezer himself in b. Ber. 28b:

When R. Eliezer became sick, his disciples entered to visit him. They said to him: "Our Master. Teach us the path of life that we may merit thereby life in the next world." He said to them: "Be careful about the honor of your colleagues, and keep your sons from meditation, and seat them in between the knees of scholars, and when you pray, know before whom you stand. And thus you will merit life in the next world."18

main functions of such structures. It should also be noted that both B1c and B3c mention death (the first, that of the Sages, the second, that of R. Eliezer).

16 In addition, R. Akiba sits before R. Eliezer (at a distance of four cubits) in B1, walks with R. Eliezer in the flashback in B2c, and mourns the prone corpse of R. Eliezer in C.

17 Anthony J. Saldarini, "Last Words and Deathbed Scenes in Rabbinic Literature," JQR 68 (1977): 28-45. The elements are: "1. Introductory phrase; 2. the disciples enter (to visit); 3. a dramatic action or question which provokes a reaction from the disciples and then a response from the master; 4 . a request for teaching; 5 . a saying or teaching; 6 . instructions (especially burial instructions); 7. exhortation; 8. prediction; 9. appointment of a successor; 10. blessing." Calderon, Literary Tropes, 168, assembles a more coherent corpus.

18 A different account of R. Eliezer's death appears in y. 'Abod. Zar. 3:1, 42c: "When R. Yohanan b. Zakkai was dying he said: Clear out the house on account of impurity and prepare a 
Other such stories are told of R. Yohanan b. Zakkai, R. Yehuda HaNasi, R. Ishmael and R. Yose b. Kisma. ${ }^{19}$ But while our story also takes place on R. Eliezer's deathbed and begins with the common introduction, "When R. So-and-so became sick ...," ${ }^{20}$ the second part inverts the more typical deathbed scene to a certain extent. For the Sages question Eliezer not in order to learn precious new traditions but rather to ascertain whether Eliezer's rulings now conform to their own, while R. Eliezer laments his disciples' lack of interest in his wisdom. In this case the "form" of the deathbed scene has been pressed into service for another purpose, namely the drama of the annulment of the ban placed upon R. Eliezer, which is the true interest of the storytellers. The use of the deathbed scene rather than another type of story for an account in which R. Eliezer bemoans his isolation and his failure to transmit traditions creates a powerful irony in light of the expected content of such stories. The initial dissonance between form and content, between the audience's expectations and the dying words of R. Eliezer, contributes to the narrative tension concerning the ultimate fate of the banned sage.

An unusual characteristic of the story is its dependence on another talmudic story, namely the banning of R. Eliezer after the controversy of the legal status of the "Oven of Akhnai."21 In general rabbinic stories are selfcontained, fictional compositions that should be interpreted on their own terms - the deathbed scene at b. Ber. $28 \mathrm{~b}$, for example, is a separate tradition which should not be reconciled with our story. ${ }^{22}$ Nevertheless, all stories assume a certain amount of knowledge, and the banning of R. Eliezer was apparently so widespread a tradition that the storytellers assumed their audience would know this element. That the Sages sit at a distance of four cubits (B1) is clearly due to his banned status, and R. Yehoshua's declaration "The vow

throne for Hezekiah King of Judah. When R. Eliezer, his disciple, was dying he said: Clear out the house on account of impurity and prepare a throne for R. Yohanan b. Zakkai." In b. Sanh. 101a R. Eliezer falls ill and various sages, including R. Akiba, visit him.

19 b. Ber. 28b; b. Ketub. 103a-b; b. Šabb. 15a; b. 'Abod. Zar. 18a.

20 Of the stories Saldarini collects, those that begin with the introductory word/phrase "When R. So-and so became sick ..." or "When he was dying, R. So-and-so said ..." are the closest to what might be designated a form. On this phrase as a literary trope see Ruth Calderon, Literary Tropes, 169-173.

21 Steinmetz, "Like Torah Scrolls," 156. On Bavli stories and aggadic traditions that presuppose or show awareness of other Bavli stories, see Jeffrey L. Rubenstein, Talmudic Stories: Narrative Art, Composition, and Culture (Baltimore, MD: Johns Hopkins University Press, 1999), 254-255; idem, Stories of the Babylonian Talmud (Baltimore, MD:Johns Hopkins University Press, 2010), 86.

22 Yonah Fraenkel, "Hermeneutical Questions in the Study of the Aggadic Narrative" [in Hebrew], Tarbiz 47 (1978): 157-161. 
is annulled" (B3c) refers directly to the ban (= vow), although it was not mentioned previously in the story. Beyond the general awareness of the tradition of R. Eliezer's banning, there are specific literary allusions to the Bavli's account of the ban as narrated in b. B. Mes. $59 \mathrm{~b}$. The portrayal of R. Yehoshua's posture-he "stood on his feet and said, 'The vow is annulled" - -alludes to the description of the same R. Yehoshua who "stood on his feet and said, 'It is not in heaven' (b. B. Meș. 59b)."23 Moreover, as we shall see below, the halakhic questions that the Sages ask R. Eliezer link to that account, and were evidently chosen deliberately to create a mental connection. These strong intertextual signs may have implications for the dating of the story, and will be considered presently.

The opening of the story is suffused with liminality. ${ }^{24} \mathrm{R}$. Eliezer lies sick on his deathbed, poised between life and death. ${ }^{25}$ The time is the eve of the Sabbath, on the threshold between day and night, between profane and sacred time. R. Eliezer has been banned, confined to the margins of the community of Sages, neither insider nor outsider. And the Sages initially station themselves in R. Eliezer's "receiving room" (traklin), on the threshold between the outside world and his inner domain. ${ }^{26}$ The term traklin (triclinium), moreover, may evoke the famous maxim of m. 'Abot 4:16: "R. Yaakov stated:This world is similar to a passageway (prozdor) to the next world. Prepare yourself in the passageway so that you can enter into the receiving room (traklin)." ${ }^{27}$ Of course there is something inherently liminal about a deathbed scene, the boundary between life and death. But here the additional liminal markers-liminal location, liminal time, liminal social status - are appropriate for the prime narrative tension, which centers on the question of the ban: will R. Eliezer die while under the ban, and therefore forever be judged an outcaste: $\mathrm{m}$. 'Ed. 5:6 directs that "they stone the coffin of anyone who dies under the ban"? Or will he be absolved and reintegrated into the rabbinic fold? His imminent death makes the resolution

23 See Goshen-Gottstein, "Lonely Sage," 91 n. 37. Likewise, the description of the Sages sitting at a distance of four cubits uses the same language as describes R. Akiba sitting distant from R. Eliezer in the "Oven of Akhnai" story.

24 See Calderon, Literary Tropes, 132-133.

25 This is clear from the opening term, keshehalah, which introduces several of these rabbinic deathbed scenes. See Calderon, ibid.

26 See Marcus Jastrow, A Dictionary of the Targumim, the Talmud Babli and Yerushalmi and the Midrashic Literature (New York, 1893; repr. New York: Judaica Press, 1989), 554; Jacob Levy, Wörterbuch über die Talmudim und Midraschim, 4 vols. (Berlin: B. Harz, 1924), 2:191. Several sources mention the traklin abutting a bedroom, as seems to be the arrangement here. See y. Roš Haš. 4:2, 59b: "Even [if they moved] from the receiving room (traklin) to the bedroom (qiton)"; b. Yoma 15b: "small rooms (qitoniot) that open to a receiving room (traklin)."

27 Or "enter the banqueting room." 
of this question a matter of urgency, as he can no longer remain in the liminal state of a menudeh. The rabbis must decide whether it is to be inside or outside.

R. Eliezer is first approached by his son Hyrcanos who wishes to remove his father's tefillin. This is ostensibly because tefillin should not be worn on the Sabbath, as clarified by the ensuing explanation: Hyrcanos should first be concerned with lighting the Sabbath lamps, for should he delay until after the Sabbath begins and then light them, he would transgress a primary category of Sabbath labor and incur a severe punishment. If he delays removing the tefillin until after the Sabbath begins, on the other hand, it is merely a matter of "Sabbath rest" (shevut), a rabbinic stringency. ${ }^{28}$ Tefillin, however, are also not to be worn after death, so it may be the imminent death, not the imminent Sabbath, that calls for their removal. ${ }^{29}$ This perspective, though apparently not shared by the characters within the story, creates an interesting irony for the audience, and contributes to the sense of urgency. At any rate, R. Eliezer's rebuke of his son suggests that the old sage is just as irascible as ever. That his rebuke makes excellent halakhic sense indicates to the Sages that his intellect is intact even as his body withers. Seeing that "his mind was lucid" the Sages approach R. Eliezer. Their purpose, as will become clear in due course, is to find a way to annul the ban. ${ }^{30}$

That the Sages enter in place of the son is a prelude to the reincorporation of R. Eliezer into the rabbinic group. Well known are the rabbinic sources that compare the relationship between master and disciple to that of father and son, and that give precedence to a disciple's obligations to his master over his father. ${ }^{31}$ To this point the banned R. Eliezer has been isolated from the community of Sages, as evident from the ensuing dialogue (Brb; "why have you not come until now?"). Though no longer a rabbinic master of the study house or academy, he has of course remained a father in his household and an authority for his sons. With the ensuing annulment of the ban his identity returns to that of a rabbinic master with bonds to disciples surpassing those to his sons.

28 Rashi, s.v. lahalots, explains the concern is that a man might leave his house and enter the public domain while wearing his tefillin, and thus violate the prohibition against carrying from public to private domains. Hence the Sages forbid wearing them altogether on the Sabbath.

29 b. Ber. 18a forbids wearing tefillin in a cemetery, and the ensuing discussion limits the rule to within four cubits of a corpse. And see Fraenkel, "Time and Its Shaping," 149.

30 Boyarin, Border Lines, 318-319 n. 114, suggests that "clarity of mind is a cipher for 'orthodoxy,' as it very frequently is in the discourse of the period (in Greek and Latin, at least)." I cannot find any other example of such a usage in rabbinic literature. The phrase always means simply that one is in possession of his mental faculties.

31 See m. B. Meș. 2:1. And see Boyarin, Carnal Israel, 211 n. 22 and the sources listed there. 
Adumbrating that movement, Hyrcanos is rebuked, baffled, and displaced by the Sages. At the conclusion of the story Akiba laments "My father, my father," explicitly embracing R. Eliezer as his spiritual father. ${ }^{32}$

Although (or because) R. Eliezer's mind is lucid, he appears none too pleased at the visit of the Sages, no doubt noticing that they sit "at a distance of four cubits" as mandated by the ban (B1). Their answer, that they have come "to learn Torah," is half-true at best. While they do intend to learn Torah, their real interest is whether R. Eliezer has renounced his views so that they may annul the ban. One might say that they have come "to learn [if the] Torah" they will hear from him now conforms to the majority view. In any case, the real reason that they have not come previously is on account of the ban. ${ }^{33} \mathrm{R}$. Eliezer immediately calls them on their dissembling (lucid!): had they truly come "to learn Torah," they surely had ample time to approach him previously, and need not have waited until his deathbed. He responds to their feeble excuse- - we had no free time" - with predictions of their martyrdom, by which the storytellers presumably allude to the traditions of persecutions of the Sages following the Bar Kokhba rebellion. This harsh and hostile prognostication (assuming it is not meant to be an expression of R. Eliezer's hopes or prayers- that would probably be too vicious for even the most bitter of Sages ${ }^{34}$ ) continues the characterization of R. Eliezer as quick-tempered and antagonistic that was evident in the rebuke of his son, and hints that there will be no easy reconciliation, despite the best intentions of the rabbis. ${ }^{35}$

This initial dialogue between R. Eliezer and the Sages also introduces R. Akiba, who will reappear twice more (B2c, C), and whose presence in the story is partly responsible for the redactional context (see below). ${ }^{36}$ Akiba thus constitutes a type of hinge that links the parts of the narrative together. That

32 Cf. Steinmetz, "Like Torah Scrolls," 163.

33 See Joseph Hayyim b. Elijah al-Hakham, Sefer Ben Yehoyada, 7 vols., ed. Yeshua b. David Salim (Jerusalem, 1998), ad loc. (4:55): "It seems that just as it is permitted to lie (leshanot) on account of [preserving peace], so it is permitted to lie to [preserve] honor, since it was not polite to tell him that they had not come because they had banned him."

34 Rashi, s.v. shelakh, explains that R. Akiba had the greatest potential, and could have learned more from R. Eliezer than the other Sages. According to Rashi, then, the harsh deaths seem to be seen by R. Eliezer as punishment. Neusner, Eliezer ben Hyrcanus, 1:41, suggests that R. Eliezer curses the Sages.

35 Goshen-Gottstein, "Lonely Sage," 84, suggests that the predictions of death are a function of the quasi-prophetic ability that Sages sometimes display on their deathbeds, and reflects no animosity or ill-will on his part. To me, this interpretation attempts to whitewash the hostility entailed in the "prophecy;" see the previous note.

36 Printings begin with "R. Akiba and his colleagues entered" in place of "Sages" but this reading is wanting in the Mss. 
his death will be "more severe" than those of his colleagues is particularly ironic in light of R. Eliezer's own observation that Akiba was the only sage who asked him questions (B2c) and who also mourns Eliezer in a deep and poignant manner (C). The alienation of R. Eliezer from even his most devoted colleagues is profound.

The second part of the story consists of R. Eliezer's parting words, but in place of transmitting traditions he laments the lack of transmission of his store of knowledge. This conception of Torah entails stasis and decline. The corpus of Torah is static insofar as he describes a fixed body of tradition, apparently revealed on Sinai and, ideally, passed down from master to disciple in its entirety. Yet Eliezer seems to concede that such ideal, complete transmission rarely occurs, as not even he himself succeeded in receiving from his teachers but a fraction of their body of knowledge, and so too his disciples from him. The inevitable result is a precipitous reduction in the body of Torah within a mere generation or two. ${ }^{37}$ This pessimistic model of stasis and decline contrasts sharply with the conception of Torah portrayed in other late Bavli narratives. When Resh Laqish dies, for example, R. Yohanan laments, "When I made a statement, the son of Laqish would object with twenty-four objections, and I would solve them with twenty-four solutions, and thus our traditions expanded" (b. B. Meș. 84a). Here dialectical argumentation opens up new interpretive possibilities which render Torah a fertile and productive enterprise. It is perhaps not accidental that R. Yohanan laments the death of the study-partner with whom he engaged in debate, whereas R. Eliezer laments his own death. For R. Eliezer, the unasked questions were not the "questions and answers, objections and solutions" of argumentation, but straightforward inquiries of law. Failure to ask therefore leads to an irremediable loss of knowledge, not the loss of possibilities of productive interchange, as in the case of R. Yohanan and Resh Laqish. When Joshua forgot 1700 traditions after the death of Moses, according to another Bavli tradition, Othniel ben Kenaz "restored them by means of his dialectical acumen" (pilpulo; b. Tem. 16a). When R. Eliezer dies, on the other hand, his traditions would seem to go to the grave with him, with no hope for restoration. ${ }^{38}$

37 So Goshen-Gottstein, "Lonely Sage," 87. Cf. Menachem Fisch, Rational Rabbis: Science and Talmudic Culture (Indiana: Indiana University Press, 1997), 64.

38 Fisch, Rational Rabbis, discusses these different models at length (which he calls "traditionalists" and "antitraditionalists"; R. Eliezer is actually an arch-traditionalist, the most extreme of various traditionalist views.) Cf. Goshen-Gottstein, "Lonely Sage," 100-106, who emphasizes the contrast between R. Eliezer, characterized in m. 'Abot 2:8 as a "limed cistern that never loses a drop," representing the model of conservative and faithful transmission of tradition, and R. Eleazar b. Arakh as an "overflowing fountain," who represents the 
In this respect the comparison of his arms to Torah scrolls is most appropriate. R. Eliezer's conception of the oral Torah he embodies resembles that of the written Torah - a finite and limited corpus of traditions, which in principle could be quantified and recorded. It is not the dynamic, growing, fertile mass of discussions, as pictured in other Talmudic sources. ${ }^{39}$ In theory, perhaps, it can be transmitted in complete and identical form such that succeeding generations possess the very same corpus of oral Torah just as they possess the same scrolls of written Torah. In practice, even in the best of cases, with the most attentive disciples such as R. Eliezer himself, a tragic decline ensues. The striking images of a dog lapping at the sea, removing but an infinitesimal amount of water relative to the whole, and an applicator stick withdrawing a trace of paint from the tube (used for making up the face), points to rapid deterioration. In less than optimal circumstances, when disciples are lazy or wanting, how much the more so! Of R. Eliezer's 300 laws of the "bright spot," not one was transmitted to a colleague or disciple, and of his 300 (maybe 3000) laws of (magic and) cucumbers, only two. Here too we sense his isolation and alienation, presumably a consequence of the same ban responsible for the Sages having kept their distance, as indicated by the first part (B1). So despite R. Eliezer learning and teaching "a great amount of Torah," he cannot prevent its loss.

Why the narrative focuses on the bright spot and "magical" manipulation of cucumbers as the traditions mastered by R. Eliezer but never transmitted to his disciples (except for two to R. Akiba) deserves some thought. From a literary perspective these examples perhaps illustrate the power and comprehensiveness of R. Eliezer's knowledge, which magnifies the tragic loss of Torah at his death. To know 300 traditions about a "bright spot," a minor element of the field of leprous impurities, demonstrates consummate expertise, as does mastery of 300 (or 3000 !) laws of the magic manipulation of cucumbers, clearly an esoteric field. ${ }^{40}$ The prominent place given to magic should give us pause

\footnotetext{
"Akiban" model of creative, generative Torah study that constantly produces novel teachings. It is not clear to me, however, that R. Eleazar b. Arakh was so identified with R. Akiba or the Akiban model of Torah study in the worldview of the Bavli, nor even that R. Akiba himself represented such a model, as most of the sources Goshen-Gottstein cites derive from elsewhere. While the Bavli storytellers went out of their way to include R. Akiba, who does not appear at all in the PT (see below), they do not employ him to thematize the contrast between these models of Torah study. Other Bavli intertexts of an alternative model of Torah study based on a different function of the master-disciple relationship therefore seem more apposite to me.

39 See e.g. b. Hag. 3 b: "Just as a plant reproduces and multiplies, so words of Torah reproduce and multiply."

40 A quick check of the concordance reveals that the term "bright spot" (baheret) appears only about 44 times in the Bavli, on 16 different folios, and "cucumbers" about 13 times.
} 
here, for the storytellers mean knowledge of magical performance, of how to do magic, as the two "laws" of magic that R. Akiba learns from R. Eliezer are quite clearly magical acts. They do not restrict this magical "law" to, say, traditions regarding magicians and magic performed by others, such as what type of punishment a magician receives. One possibility is that R. Eliezer's performance of the magical harvesting again underscores his uniqueness and non-conformity, which perhaps hints that R. Eliezer has not changed his ways despite the ban, anticipating the similar lack of change of his halakhic positions to be revealed shortly $\left(\mathrm{B}_{3} \mathrm{C}\right) .{ }^{41} \mathrm{R}$. Eliezer always has and always will stand apart from the majority of the sages, both in his problematic halakhic rulings and the problematic subjects of knowledge. Such a reading assumes that magic, or at least such magical acts, would have been considered problematic or even forbidden, by the storytellers and their audience. ${ }^{42}$ However, recent scholarship has argued that the rabbis' attitudes to magic were ambivalent and conflicted, and numerous Talmudic traditions report rabbis doing magic of various sorts. ${ }^{43}$ Indeed, there appears to be a shift from the Tannaitic to Amoraic sources, with the Tannaim prohibiting magical acts, as does $\mathrm{m}$. Sanh. 7:11, the mishnah with which the story is juxtaposed, and the Amoraim routinely engaging in magic. In this respect the story represents R. Eliezer in the manner of some Amoraim, who display mastery of both Torah and magical praxis. ${ }^{44}$

41 In this respect I disagree with Boyarin's interpretation: “We can read this shift within the narrative at the moment when Rabbi Eli'ezer turns from magic planting and harvesting of cucumbers to answering the Rabbis' purity question. He moves, as it were, from one episteme to another, accepting the terms of the new regime. Thus the story becomes a mini-historical allegory of the shift in the social status of ongoing dialectic from the second- and third-century to the fifth- and sixth-century context" (Border Lines, 179). I do not see a shift here. R. Eliezer had just mentioned laws of the bright spot, a matter of purity law, before the laws of planting cucumbers. That the Sages ask about purity law, and that R. Eliezer answers, is unexceptional, and need not indicate an epistemic shift. See below on the reasons for these specific questions about purity law. And from his answers to the Sages' purity questions it is clear that R. Eliezer has not "accepted the terms of the new regime."

42 The anonymous Talmud raises this problem in its discussion of the story. See below, "Redactional Context."

43 Gideon Bohak, Ancient Jewish Magic: A History (Cambridge: Cambridge University Press, 2008), 351-425, and the references there; Kimberley Stratton, "Imagining Power: Magic, Miracle, and the Social Context of Rabbinic Self-Representation," JAAR 73 (2005): 361-393, and eadem, Naming the Witch: Magic, Ideology, and Stereotype in the Ancient World (New York: Columbia University Press, 2007), 143-176.

44 This point only confirms that the narrative, though introduced by the technical term "Was it not taught" (vehatanya), is a pseudo-baraita, as is common with late stories. See Rubenstein, Talmudic Stories, 261-262, and Stories of the Babylonian Talmud, 214-215. 
Another possibility emerges from Joshua Levinson's observation that the Bavli tends to conceptualize magic differently than the Yerushalmi. For the Yerushalmi magic is an autonomous realm, a discrete cultural practice, though one which rabbis may engage in, with varying degrees of success. The Bavli, by contrast, treats magic as a component of Torah, such that we witness "an actual transformation of magic into law, into a type of legal tradition that must be studied and transmitted." ${ }^{25}$ Levinson also suggests that the 300 laws of the bright spot is chosen as "a topic specifically tied to the priesthood. The discourse of Torah in the Bavli is appropriating all possible sources of competing knowledge and authority."46 If so, the choice of these two legal topics emphasizes the breadth of R. Eliezer's Torah, which included everything, from priestly knowledge to magical tradition, from $\mathrm{A}$ to $\mathrm{Z}$ as it were. In both breadth and depth (3oo laws) his knowledge of Torah was unparalleled, which enhances the tension and urgency of the Sages' task upon his death, as well as the tragedy of his marginalization throughout his life.

At this point the Sages ask R. Eliezer specific halakhic queries, a poignant and ironic narrative transition in light of his lament at the lack of questions for much of his life (B3). Their questioning can be interpreted as a sympathetic gesture, as a compassionate, if belated, response to his desire for inquiries so as to offer some consolation before his death. Yet the audience soon learns from R. Yehoshua's declaration that these questions are the true purpose of their visit, an attempt to rehabilitate R. Eliezer by ascertaining whether he has recanted his views or not. They come not to console R. Eliezer, but to interrogate him. The first question concerns the susceptibility to impurity and the processes of purification of five objects that were the subject of disputes between R. Eliezer and the Sages, as we know from sources found in the Mishnah and Tosefta. These are objects covered with leather, and the disputes turn on whether, from a legal point of view, they are considered receptacles (since the covering is closed or sealed, and not meant to be opened or removed), and second, the manner of purification in the event the covering tears open. ${ }^{47}$

45 Joshua Levinson, "Enchanting Rabbis: Contest Narratives between Rabbis and Magicians in Late Antiquity," JQR 100 (2010): 54-94; cf. the Hebrew version, "Boundaries and Witches: Stories of Conflicts between Rabbis and Magicians in Rabbinic Literature" [in Hebrew], Tarbiz 75 (2006): 295-328. See, however, Shamma Friedman, "Now You See It." "Enchanting Rabbis," 73. Cf. Boyarin, Border Lines, 180.

47 Rashi, ad loc., s.v. mahu. Other commentators explain the laws at issue here in slightly different ways. The objects are: (1) a leather ball, filled with stuffing; (2) a shoemaker's last, made of leather and stuffed, (3) an amulet with a leather covering, (4) a leather bag holding pearls (or leather covering a pearl worn as a necklace), (5) a weight, probably made of lead and covered with leather. If the leather covering tears open then the Sages con- 
One of these objects is a shoemaker's last, which is mentioned in the Sages' second question, whether a shoe which has yet to be removed from the last (but the manufacturing process of which is otherwise finished) is considered complete, hence susceptible to impurity, or not fully complete, hence not susceptible to impurity. ${ }^{48}$ The "shoe on the last" in turn recalls the cause of the ban of R. Eliezer. ${ }^{49}$ For this issue is the third of the four objects listed in t. 'Ed 2:1 as the subjects of debates between R. Eliezer and the Sages, the last of which is the Oven of Akhnai, the subject of the dispute that caused the banning of R. Eliezer. ${ }^{50}$

cede that the objects are susceptible to impurity and rule that the inside stuffing must be removed before the objects can be immersed for purification, i.e., that the stuffing is deemed a "separation" (hatsitsa). R. Eliezer rules that they may be immersed "as they are," i.e., without removing the stuffing. These five objects do not appear in any single Tannaitic source. The first three appear together in m. Kelim 23:1 (which only transmits the Sages' opinion) and t. Kelim B. Bat. 2:6, which adds R. Eliezer's disagreeing opinion (some texts of t. Kelim B. Bat. 2:6 read "R. Eleazar b. Azariah" in place of R. Eliezer; see Gilat, R. Eliezer, 391 n. 168 , on this issue). The Sages and R. Eliezer disagree over the bag for pearls in t. Kelim B. Bat. 4:3. I cannot find a disagreement over a "small weight" in Tannaitic sources, though the purity of a weight is discussed in m. Kelim 12:8 and 26:6, and t. Kelim B. Bat. 7:12. See Tosafot, ad loc., s.v. utaharatan. It appears that the storytellers had some other traditions concerning R. Eliezer's purity rulings that are not attested in our sources, though the overall positions of R. Eliezer and the Sages are consistent. On this issue see Gilat, R. Eliezer, 389-391, and the footnotes there; Hesdai David to t. Kelim B. Bat. 2:6. Alon, "Lonely Sage," 92-93, argues that the questions cannot be a test, given the lack of explicit disputes over these exact objects in the Tannaitic sources, and considers them an effort to study Torah, to act as the disciples R. Eliezer never had. These understandings are not necessarily mutually exclusive. It seems too much a coincidence to see these questions about purity, so close to the issue that led to the ban in b. B. Mes. $59 \mathrm{~b}$, as randomly selected. And see below concerning the "shoe on the last" in t. "Ed. 2:1.

48 Steinmetz, "Like Torah Scrolls," 166-167, argues at length that the objects should be seen as metaphors for R. Eliezer, as they have some sort of filling, but are closed up, and R. Eliezer's lament over his arms like rolled up Torah scrolls means that he "sees himself as a container of Torah, Torah that is being rolled up and that never will be able to be accessed by others- - he is a receptacle filled with Torah that will forever be sealed inside." I think this suggestion is a little speculative, as the metaphors are not straightforward, and the motivation for including this source can be explained more simply, but is perhaps worth considering. (However, Steinmetz's efforts to include tefillin with this list of objects, as it is sometimes included in some of the Tannaitic sources, are not convincing to me. This reading requires that the audience know the relevant Tannaitic sources in Mishnah and Tosefta, realize that some of those sources mention tefillin whereas the Sages' question in the story does not, reflect upon that absence, and make a connection to the earlier scene. This asks too much of the audience.) See too Goshen-Gottstein's interpretation of the shoe on the last as "unfinished" in the same way as R. Eliezer himself is "unfinished" insofar as the Sages never came to learn his Torah ("Lonely Sage," 94).

49 See Steinmetz, "Like Torah Scrolls," 166; Goshen-Gottstein, "Lonely Sage," 93-94.

$50 \quad$ b. B. Meș. 59a; y. Mo'ed Qaț. 3:1, 81c-d. 
Four things R. Eliezer rules pure and the Sages rule susceptible to impurity ... (3) The shoe on the last: R. Eliezer declares pure and the Sages rule susceptible to impurity. ${ }^{51}$ (4) If one cut it [an oven] into segments and placed sand between the segments, R. Eliezer rules it pure and the Sages rule that it is susceptible to impurity. And it was called the Oven of Akhnai, for disputes about it multiplied in Israel.

Thus the story's first question recalls the general issue that led to the ban (disputes over purity/impurity) and mentions the "shoe on the last" specifically. It is the perfect segue to the second question, whether a "shoe on the last" is susceptible to impurity, which in turn triggers the audience to think of the Oven of Akhnai and the ban, although the Oven of Akhnai itself is elided. Together with the intertextual signs mentioned above, the storytellers have placed a significant allusion to the account of R. Eliezer's banning in the mouth of the Sages, with brilliant effect. From the audience's perspective, the Sages ask: "After all these years of the ban that devolved from R. Eliezer's refusal to adhere to the majority ruling about the oven cut into segments, will he now accept their ruling regarding the shoe on the last, which appears in that same list of disagreements?"

R. Eliezer, alas, remains true to his former position, as attested in those same sources in the Mishnah and Tosefta. His recalcitrance puts the Sages in a bind. They cannot remove the ban because R. Eliezer has not retracted his opinion. But time is running out, as R. Eliezer's death is imminent. The temporal setting helps communicate this sense of urgency. In the first part the imminent commencement of the Sabbath makes it urgent to act, so urgent that Hyrcanos is instructed to attend to the Sabbath lamps before removing the tefillin. Action must be taken now to remove the ban, as R. Eliezer's death approaches, and perhaps-although not explicitly stated—we are to imagine that the Sabbath is drawing to a close as well. That R. Eliezer also mentions in the first scene that violation of the imminent Sabbath entails death by stoning reinforces the link between the Sabbath and death. The sacred life of R. Eliezer is expiring as the sacred time of the Sabbath inexorably ticks away toward its close. Here the narrative tension builds to a climax. He wants to teach his Torah before his death.

$5^{1} \quad$ The issue here concerns at what point the shoe is complete, as utensils are only susceptible to impurity when their manufacture is complete. R. Eliezer rules that the shoe is not finished until removed from the last, hence the shoe is "pure," i.e. not susceptible to impurity. The Sages rule that the shoe has been completed and is susceptible to impurity. The debate between R. Eliezer and the Sages also appears in m. Kelim 16:4. See Gilat, R. Eliezer, 52 , and notes. 
The Sages want to lift the ban before his death. But the Torah he teaches, his refusal to retract his former rulings, affords no justification to do so.

No legal justification, that is. So R. Yehoshua turns to a supernatural justification. He interprets the fact that R. Eliezer's last word was "pure" as a divine sign, a revelation of the divine will, indicating that the Sages should make Eliezer "pure" and rehabilitate him. ${ }^{22}$ His declaration "the vow (= ban) is annulled" is appropriately non-legal, i.e. not following standard legal protocol. ${ }^{53}$ And of course R. Eliezer's death makes the whole question non-legal almost by definition, though there are the posthumous consequences noted above, including the stoning of his coffin. Nevertheless, in light of the ensuing profound expressions of grief, the rescinding of the ban should not be judged either gratuitous or moot, but as the long sought resolution to a disturbing estrangement. The allusion that the storytellers contrived to the story of R. Eliezer's banning contributes to this sense of closure. Where once "R. Yehoshua stood on his feet and said, 'It is not in heaven'" (b. B. Mes. 59b), ${ }^{54}$ here the same R. Yehoshua (who was not mentioned previously in our narrative) makes the same gesture for quite the opposite purpose. Having formerly rejected an explicit heavenly voice, which led to the banning of R. Eliezer, he now heeds a heavenly sign and overturns the ban.

In Part [C], R. Eliezer has died, and the funeral is under way. There is a slight incongruity in that R. Akiba appears to have been among the Sages present at R. Eliezer's death, presumably in the same room, but now encounters the funeral procession "between Caeserea and Lod," which seems to imply he was not present to grieve at the death, unless we are to imagine the Sages all dispersed after the death and then returned to the scene of the funeral. ${ }^{55}$ The

$5^{2}$ Note that the storytellers chose for the Sages' final question to R. Eliezer one to which he would answer "pure." The story would not work if they chose an issue that R. Eliezer ruled "impure." See too the reading of ms HaRav Herzog in the appendix where a heavenly voice pronounces R. Eliezer "pure," making this point abundantly clear.

53 Though it must be conceded that narratives often do not follow halakhic protocol.

54 See Joseph Chaim, Sefer Ben Yehoyada, ad loc., who suggests that R. Yehoshua, "intended to act in annulling the vow in the same manner he acted on the day of the vow, where he stood on his feet and said, 'It is not in heaven.' Of course we would attribute the intention to the storyteller, not the character.

55 Shraga Bar-On (oral communication) has suggested to me that R. Akiba's question (and R. Eliezer's vicious answer) in bi(c) is a later addition, and not part of the original story. Removing that line would obviate this problem of R. Akiba encountering the procession elsewhere, and has much to recommend it in my opinion, though there is no textual evidence to support the conjecture. (It would also make for a more precise structure, as bi(c) in my structure in fact contains two questions.) Cf. the discussion of the PT parallel below, where R. Akiba does not appear at all. 
comparison to the Yerushalmi version below will provide some help in resolving this question. In any case, R. Akiba's violent grieving, "striking his flesh until the blood gushed upon the earth," is consistent with the violent tenor of Bavli stories. ${ }^{56}$ Yet it is unprecedented among other such stories of rabbinic deathbed scenes, where disciples typically cry or lament, but do not cause self-inflicted wounds. That injuring one's body risks running afoul of a biblical prohibition, an issue that puzzled the commentators, underscores how unusual this reaction is. ${ }^{57}$ Here it continues the motif of violence that surfaced in R. Eliezer's cruel predictions of the Sages' death (B1), as well as his rebuke to his son (A3 $_{3}$; an example of verbal, not physical violence). It can also be understood as a sign of the emotional trauma that resulted from the whole affair. The banning of a great sage, the suffering that the Sages knew they had caused by the ostracism and isolation, and then this difficult and ambiguous final encounter culminating in R. Eliezer's death causes R. Akiba, and perhaps his colleagues, a harrowing experience of grief, remorse, frustration, regret, guilt, and anxiety.

And loss: R. Akiba cites Elisha's words upon seeing his master Elijah carried away by the whirlwind (2 Kgs 2:12), hardly the verse one would expect at the death of a Sage who had been ostracized for so many years. ${ }^{58}$ It expresses the deep loss that R. Akiba, and presumably other Sages too, experiences at the death of a great master and at the years of lost opportunity to learn his Torahthe loss of traditions that R. Eliezer lamented earlier. R. Akiba's reference to R. Eliezer as his "father," which returns to the theme of spiritual sons/disciples and biological sons raised in the first part $\left(\mathrm{A}_{1}-\mathrm{A}_{3}\right)$, contributes to the enormity of their loss. For R. Eliezer was not just a venerable sage, but the master/spiritual father of the Sages, and they his true (spiritual) sons. ${ }^{59}$ Indeed, rabbinic sources elsewhere adduce this verse as a prooftext for the common topos that disciples are as sons and masters as fathers, as Elisha and Elijah serve as a

56 The Culture of the Babylonian Talmud (Baltimore, MD: Johns Hopkins University Press, 2003), 54-66. This type of (real) violence, however, is not exactly the same phenomenon as the verbal violence of the academy. But that verbal violence sometimes is represented as physical and spills over into other arenas.

57 See Tosafot, ad loc., s.v. hayah.

$5^{8}$ The same words are pronounced by King Yoash on the deathbed of Elisha (2 Kgs 13:14), a biblical deathbed scene.

59 This point is hinted at by editor of Tractate Semahot 9:2-3. He claims that, at the death of R. Eliezer, R. Akiba bared both of his arms, while at the death of his father he did not bare his arms. Dov Zlotnick, The Tractate "Mourning" (New Haven: Yale University Press, 1966), 145, notes: “'R. Akiba bared both arms,' etc.- -although he refrained from doing so in the case of his father." 
paradigmatic example of the master-disciple relationship. ${ }^{60}$ Thus R. Akiba confesses that he has "many coins," i.e. many traditions and questions, and "no money changer to sort them." He has no master to explain the reasoning behind the traditions and to provide answers for the questions in the same way as a moneychanger identifies the qualities of the coins and assesses their relative values. ${ }^{61}$ From this eulogy too we see that R. Eliezer's accusation that the Sages had not learned his myriad traditions was not the deluded ravings of a bitter, dying sage, but the truth. Those hundreds of traditions about leprous spots and cucumbers and many other subjects were lost with R. Eliezer, together with a great many other matters concerning which the Sages lack knowledge. And that, for the Sages, is tragic.

In the end R. Eliezer receives the appropriate, honorary funeral for a rabbinic master-with a ritual procession, rows of mourners, and a eulogy from a prominent sage. Unlike Akavia b. Meahalalel, his coffin is not stoned; unlike Elisha b. Abuyah, there is no fire burning upon his grave. ${ }^{62}$ In death, R. Eliezer has been successfully reincorporated into the rabbinic fold, though the lost years cannot be redressed.

Ultimately the story should be seen in terms of several tensions of the rabbinic worldview, primarily the tension between rabbinic commitments to masters of Torah and to the integrity of the legal system. For the storytellers, the

6o See Sipre to Deuteronomy \#34 (ed. L. Finkelstein [New York: Jewish Theological Seminary, 1983], 61): "Your sons (Deut 6:7). These are your disciples, as it says ... And just as disciples are called sons, so the master (rav) is called a father, as it says, Elisha saw it, and he cried out, 'My father, My father! Israel's chariots and horsemen' (2 Kgs 2:12)." According to Sipre to Deuteronomy \#305 (p. 327), Joshua eulogized Moses, "My father, my father! My master, my master." b. Meg. 26a cites this verse as a prooftext for the law that one tears his clothes in mourning for both parents and masters. On the meaning of the expression in its biblical context, see M.A. Beek, "The Meaning of the Expression 'The Chariots and the Horsemen of Israel' (2 Kings ii 12)," in The Witness of Tradition: Papers Read at the Joint British-Dutch Old Testament Conference Held at Woudschoten, 1970, ed. M.A. Beek (Leiden: Brill, 1972), $1-10$.

61 See Shlomo Naeh, "On Structures of Memory (and the Forms of Text) in Rabbinic Literature" [in Hebrew], in Mehqerei Talmud 3, ed. Y. Sussman and D. Rosenthal (Jerusalem: Magnes, 1990), 545-546 and n. 16, who shows that metaphors of money and moneychangers are strongly associated with memorization of Torah, each and every tradition in the correct place like money in the moneychanger's storage box. The metaphor is thus particularly apt for the type of Torah R. Eliezer embodies. Among the sources Naeh collects, see especially Sipre to Deuteronomy $\#_{13}$ (p. 22): "What is the difference between a sage (hakham) and a wise man (navon)? The sage is similar to a wealthy moneychanger ..." and Sipre to Deuteronomy \#48 (pp. 107-108).

62 m. 'Ed. 5:6; b. Hag. 15b; y Ḧag. 2:1, 77b-c. 
incredible merit that ought to accrue to a sage like R. Eliezer on account of his prodigious knowledge of Torah stands in tension with the account of his banning, even if they recognize the need to marginalize individual sages who oppose the decisions of the majority. How can a sage with such a mastery of Torah be treated as a pariah? How can they allow his vast knowledge of tradition to be lost? Should they sacrifice the potential answers to many halakhic problems for the sake of the good of the system? And how can the merit of R. Eliezer's Torah fail to be salvific, as it would appear to be should he die under the ban?

The tension recalls that posed by the story of Elisha b. Abuyah, where the storytellers contemplate whether Torah and sin can coexist, whether a master of Torah also can be and die a sinner, with the concomitant posthumous consequences. ${ }^{63}$ Just as that story explores these questions through the relationship between Elisha b. Abuyah and his disciple R. Meir, so our story explores them through the relationship between R. Eliezer and his disciple R. Akiba. Transmission of Torah, including problematic Torah, is a function of the masterdisciple relationship, and is inevitably scrutinized through that prism. The story of Elisha b. Abuyah posits a posthumous rehabilitation where Torah ultimately prevails over heresy and sin such that Elisha enters the next world. This resolution is analogous to R. Eliezer's quasi-posthumous rehabilitation. Here we might say that R. Eliezer's Torah prevailed over his "heresy" of violating of rabbinic protocols and allowed him to be buried and mourned as a beloved sage rather than a reviled menudeh. Our story focuses more on the psychologicalemotional dimension of the tension, the story of Elisha b. Abuyah on the theological dimension. ${ }^{64}$ In both cases the inherent merit of Torah proves to be inviolable.

\section{The Pт Version and the вт Reworking}

A version of the account of R. Eliezer's death appears in y. Šabb. 2:5, 5 b. (There is also a version in 'Abot R. Nat. A 25 which I will not discuss due to the notorious difficulties in determining the dating and provenance of this text. ${ }^{65}$ )

63 See Rubenstein, Talmudic Stories, 64-104.

64 Several non-narrative comments within the Elisha b. Abuyah narrative pose the theological question almost explicitly; see Rubenstein, Talmudic Stories, 79-80.

65 On this version see Goshen-Gottstein, "Lonely Sage," 79-80. There are also parallels to parts of the story in Song Rab. 1:3; see Goshen-Gottstein, "Lonely Sage," 106-107. 
y. Šabb. 2:5, $5^{b}$

(I) It happened that when R. Eliezer was dying (goses)

At the eve of the Sabbath, at dusk

Hyrcanos, his son, entered to remove his tefillin. He said to him, "My son. You neglect the commandment of the Sabbath-lamp, which is [a matter of] Sabbath-rest (shevut), and is punishable by excision, and you come to remove tefillin, which is merely discretionary (reshut) and merely a mitzvah."

He went out screaming and saying, "Woe is me, for my father's mind is confused." He [Eliezer] said to him, "Your mind is confused. My mind is not confused."

(II) When his disciples saw that he [R. Eliezer] had answered him [Hyrcanos] intelligently, they entered before him.

\section{b. Sanh. $68 \mathrm{a}$}

When R. Eliezer became sick, the Sages entered his [abode].

He was sitting on his canopied bed, and they were sitting in his receiving room.

[A2] That day was the eve of the Sabbath, and Hyrcanos, his son, entered to remove his tefillin. He [R. Eliezer] rebuked him [Hyrcanos] and he left in disgrace.
[A3] He [Hyrcanos] said to them, "Colleagues of my father. It seems that my father's mind is confused." He [R. Eliezer] said to him, "Your mind and Your mother's mind are confused. How can one neglect a prohibition [punishable by] stoning, and busy oneself with a prohibition [that is merely a matter] of Sabbath rest [shevut]?"

[B1] When the Sages saw that his mind was lucid, they entered and sat before him at a distance of four cubits

(a) He said to them, "Why have you come?" They said, "We have come to learn Torah."

(b) [He said to them, "Why have you not come until now?" They said to him, "We had no free time." 
(cont.)

(c) He said to them, "I will be amazed if you all die natural deaths." R. Akiba said to him, "What about my [death]?" He said to him, "Yours will be more severe than theirs."

[B2] (a) He took his two arms and placed them on his chest. He said, "Woe to you, my two arms, which are like two rolled Torah scrolls. I have learned a great amount of Torah and I have taught a great amount of Torah. I have learned a great amount of Torah-and I did not take away from my masters even as much as a dog laps up from the sea. I have taught a great amount of Torah-yet my students have not taken away from me even as much as a painting stick [takes out] of its tube.

(b) "Not only that, but I recite 300 laws about the bright spot and no one ever asked me a question about them.

(c) "Not only that, but I recite 300 lawssome say 3000 laws - about the planting of cucumbers, and no one ever asked me a question about them, except for Akiba b. Yosef: Once he and I were walking on our way, and he said to me, 'My master. Teach me one thing about the planting of cucumbers.' I said one thing, and the whole field filled up with cucumbers. He said to me, 'My master: You taught me about their planting. Teach me about their uprooting.' I said one thing and they all gathered in one place." 
(cont.)

y. Šabb. 2:5, 5b

b. Sanh. $68 \mathrm{a}$

They were asking him [questions] and he was answering them. About that which [B3] (a) They [the Sages] said to him: was impure he answered "impure" and about the pure he answered, "pure."

"Master: A ball, a shoemaker's last, an amulet, a bag for pearls and a small weight — what is the law?" He said to them, "They are susceptible to impurity, and they are made pure [by immersion] as they are."

(b) [They said to him] "A shoe on the last-what is the law?"

In the end he said "Pure."

He said to them, "It is pure."

And his soul departed. They said, "It is

(c) And his soul departed with "Pure." clear that our master is pure."

R. Mana said, "Even before this it was clear." $^{\prime 66}$

(III) R. Yehoshua entered and removed

R. Yehoshua stood on his feet and his tefillin. He was hugging him, and kissing him, and crying, and saying, "My said, "The vow is annulled. The vow is master! My master! The vow is annulled. annulled."

[C] After the Sabbath, R. Akiba encountered him [R. Eliezer's funeral procession] between Caeserea and Lod. He [Akiba] was striking his flesh until the blood gushed upon the earth.

My Master! Israel's chariot and horsemen In the row [of mourners] he [Akiba] (2 Kgs 2:12)." began [his eulogy, and said]: "My father! My father! Israel's chariot and horsemen" (2 Kgs 2:12).

66 This can also be translated: "Was it not clear before now?" 
I have many coins and no moneychanger to sort them."

The PT version is briefer and less developed than that of the BT, as is typical. From the shared elements it is clear that the PT story (or an extremely similar version) was the source of the BT story. Thus the first scene of the PT is extremely close to that of the BT: the dying R. Eliezer is approached first by his son, who tries to remove the tefillin, but is rebuffed with a complex halakhic argument that he fails to understand. ${ }^{67}$ At this point he is approached by a group of rabbis (in this version, "his disciples," as opposed to BT's "Sages"), who have perceived from R. Eliezer's words that he is lucid. In the second scene, as in the BT, the disciples/Sages ask R. Eliezer halakhic questions. His last word is "Pure," and, in the third scene, R. Yehoshua declares that the "vow"/ban is annulled. The eulogy features the same verse from 2 Kings 2:12.

Yet it is just as clear, from the differences, that the BT storytellers have reworked the story in significant ways:

(1) A major transformation is the addition of R. Eliezer's long soliloquy (B2), lamenting the loss of Torah and the lack of questions, despite his prodigious knowledge of $300 / 3000$ laws of the bright spot and 300 of (magical) planting of cucumbers. All this has no trace in the PT, in which the theme of the decline and loss of Torah, so crucial to the BT, is absent. Consequently, the PT also lacks the second part of R. Akiba's eulogy, the figure of the moneychanger, which mourns the loss of a teacher who could answer questions. The PT story is about the death of a sage and master, but not about the tragic loss of Torah because he has failed to transmit it during his life.

(2) R. Akiba appears thrice in the B T (B1c, B2c, C) but nowhere in the PT. The BT storytellers have added the special (only R. Akiba asked questions of, and walked with, R. Eliezer) yet strained (R. Akiba's death will be the most painful) relationship between R. Akiba and R. Eliezer. ${ }^{68}$ Thus the theme of the master/disciple relationship is specific to the BT.

67 On R. Eliezer's argument and the use of this halakhic terminology, see Gilat, R. Eliezer, 161-163, 19o; Fraenkel, "Time and Its Shaping," 150-151, and his references to comments by Lieberman and Epstein in nn. 44, 47.

68 R. Eliezer's claim that R. Akiba alone asked him questions points to some special relationship, as does R. Akiba's painful eulogy. See Goshen-Gottstein, "Lonely Sage," 83, 95-97. 
(3) The hostile tenor of the story is new in the BT, including R. Eliezer's prophecies of the untimely death of the Sages and the cruel death of Akiba (Bic), Akiba's violent mourning (C), and even R. Eliezer's "rebuke" of Hyrcanos who leaves "in disgrace" (A2; in the PT R. Eliezer simply explains to Hyrcanos why the tefillin should not be removed.) The palpable sense of the resentment expressed by R. Eliezer that pervades the BT story appears nowhere in the PT, which is told of his "disciples," not "the Sages." Indeed, the PT has R. Yehoshua hugging and kissing R. Eliezer after the death, where the в т has Akiba "striking his flesh until blood gushed." This shift from gestures of love and intimacy to pain and self-mortification is emblematic of the difference in tenor in the two stories.

(4) The BT substantively transforms the questioning of R. Eliezer. The PT simply relates that the Sages questioned R. Eliezer but does not detail the exact issues they asked. The вт, in contrast, reports the specific questions which, as we have seen, directly recall the ban. More significantly, in the PT R. Eliezer's answers reveal that he no longer disputes with the majority: "about that which was impure he answered 'impure' and about the pure he answered, 'pure." He therefore deserves to be released from the ban, and we can understand why R. Yehoshua states that the vow/ban is released. In the вт, by contrast, R. Eliezer's answers reveal that he has not changed his mind, hence there are no legal grounds for removing the ban.

(5) In this respect the вт has made the issue of annulling the ban the central tension of the story. As noted, the purpose of the Sages' visit is to accomplish this task, and their questions are to ascertain whether R. Eliezer has retracted. While the ban is explicitly mentioned in the PT, it is not clear that the rabbis visit him on that account, nor how central it is to the storytellers' message. There is no mention of the rabbis sitting four cubits distant from R. Eliezer, nor of their not having "come until now" (B1; apparently on account of the ban), nor of all the Torah that has been lost (B2), again due-at least in part-to the Sages having kept apart from R. Eliezer. Now it is possible to read the PT along the same lines as the вт: the rabbis (= his disciples) ask questions to see whether R. Eliezer still rejects the majority view and find that he has indeed retracted. While they are now justified in removing the ban, he dies before they can do so. But since he has died saying "Pure," the rabbis consider this as evidence that the ban is lifted and state, "Our master is pure," and the "Vow is annulled." With this reading there remains the significant difference in that R. Eliezer has retracted in the PT, whereas in the вт he has not. In the Pт the last word "Pure" confirms that the ban should be lifted, whereas in the вт it provides the mechanism, a type of legal fiction that effects the removal of the ban. In the PT, in other words, the word "Pure" testifies to R. Eliezer's "orthodoxy"; in the в 
it functions as a sign that despite his nonconformist answers God has released the ban, as it were.

However, I think another reading is plausible, namely that the removal of the ban is not the purpose of the visit or the questions, and is mentioned almost as an afterthought following his death. R. Eliezer's own disciples, not "the Sages," visit him in the PT, and there is no evidence they have been keeping apart from him (whatever the other Sages have been doing.) They presumably visit him to be present at his death, as in other rabbinic "deathbed" scenes, and as in the alternative deathbed scene of R. Eliezer himself in b. Ber. $28 \mathrm{~b}$ mentioned above. The questions they ask are the typical discussions of Torah that students have with their masters, and the narrator affirms that R. Eliezer answers correctly to emphasize that his mind was lucid to the end, and to have his dying word be "Pure." This functions simply to indicate how holy and pure R. Eliezer was at his death. The comment by R. Mana emphasizes that they knew all along that R. Eliezer was pure, even before this dying word. Note that in the PT R. Yehoshua does not say that the vow is annulled immediately after R. Eliezer's final word, but only after entering and removing the tefillin, in the third, not the second, scene. The dying word "Pure," in other words, does not function either as expression of conformity or as supernatural sign that the vow is annulled, but a sign of holiness. In b. B. Mes. 86a Rabbah bar Nahmani also dies with the word "Pure" on his mouth, and there is no issue of a ban. ${ }^{69}$ Our awareness of the в т makes it hard to judge whether this alternative reading is persuasive. In any case, whatever the force of the annulment of the ban in the PT, in the в $\mathrm{T}$ it takes center stage.

(6) The eulogy of the Рт has been greatly expanded in the в $\mathrm{T}$ into a discreet scene that takes place in a different location, with the violent gestures noted above replacing the irenic hugging and kissing. The verse ( 2 Kgs 2:12) is quoted verbatim in the Bavli ("My father, my father") rather than paraphrased ("My master!"). Most significantly, the mourner/eulogizer has shifted from R. Yehoshua in the PT to R. Akiba in the вт. ${ }^{70}$ The relentless use of pronouns renders it ambiguous as to whom $\mathrm{R}$. Akiba encountered such that it is possible to read that R. Akiba met R. Yehoshua while the latter struck his flesh and pronounced the eulogy. This reading, however, is less plausible, given the focus on R. Akiba and his relationship with R. Eliezer earlier in the story, and because it would entail that R. Yehoshua switch from object to subject: "R. Akiba encountered him [R. Yehoshua] between Caesera and Lod. He [R. Yehoshua] was strik-

69 Cf. b. 'Abod. Zar. 27b where R. Ishmael says of Ben Dama, "Your soul departed in purity."

70 See Goshen-Gottstein, “Lonely Sage," 95. 
ing his flesh"; I have not found any commentators or translators who read the last scene this way. This switch to R. Akiba as subject—even with the ambiguity-is a striking example of the transformation that occurs in the process of reworking rabbinic sources, and the type of wholesale invention of biographical anecdotes about sages that can occur in this process. ${ }^{71}$

The BT reworking of the scene helps account for the incongruity noted above that R. Akiba is among the Sages present at the death of R. Eliezer, but then strikes his flesh upon encountering the bier, apparently that night or the next day, as if he had not witnessed the death itself. The вт has reworked the Pт narrative, which reads smoothly: the disciples/Sages are present at the death and the eulogy is immediately pronounced. The вт displaces the eulogy to a later time and a different place, for reasons that are not completely clear, ${ }^{72}$ which produces the problem locating R. Akiba.

(7) There are a number of other minor differences less central to the meaning of the narrative, though interesting from a compositional perspective, including the halakhic argument of R. Eliezer, ${ }^{73}$ the configuration of R. Eliezer's house, ${ }^{74}$ and the removal of his tefillin after his death. ${ }^{75}$

71 See e.g. Shamma Friedman, "La'aggada hahistorit batalmud habavli," in Saul Lieberman Memorial Volume, ed. Shamma Friedman (New York: Jewish Theological Seminary, 1993), 128, 134. Also Cf. Hippolyte Delehaye, The Legends of the Saints: An Introduction to Hagiography, trans. V.M. Crawford (London: Longmans, Green and Co., 1907), $78 \mathrm{ff}$.

72 Perhaps the displacement of the eulogy and dramatic funeral emphasize that R. Eliezer received an honored burial despite his years of being banned. R. Eliezer is associated with Lod in various sources, e.g. b. Sanh. 32b; t. Sukkah 2:1. Cf. y. Ketub. 2:5, 26c.

73 See n. 67. The difficult phrasing of the PT perhaps motivated the substitution of a more straightforward explanation in the вт.

74 This change is particularly instructive. The action depicted in the first scene of the PT is relatively straightforward. No setting is given, and we should understand that the entire scene takes place in the same room, evidently R. Eliezer's bedroom or another room of his abode where his deathbed has been placed. Hyrcanos approaches his father to remove the tefillin, but Eliezer refuses and offers the complicated halakhic explanation. Hyrcanos does not understand the argument; lamenting that his father has lost his senses, he begins to weep. R. Eliezer responds that his own faculties are intact and his son (perhaps because of the distress at seeing his father dying) is confused. Having witnessed this interchange but understood R. Eliezer's halakhic demonstration, the disciples then approach R. Eliezer's bed, and the story proceeds with their questions. Yet there is a subtle ambiguity in this account in that the storyteller uses the language "entered" (nikhnas) and "went out" (yatsa) to describe Hyrcanos's movements, and likewise "entered" to describe that of the disciples. In this context these terms simply mean "approach" and "move away." We are to imagine that the disciples are within the same room, but in the background, at some distance from the bed, while Hyrcanos stands right next to his father's bed, and then walks away from it toward the disciples. The BT storytellers seem to have taken the admittedly ambiguous words more literally in the sense of "entered his room from another" and "went 
These transformations encompass the major themes of the Bavli story which emerged from the literary analysis, including the centrality of the ban of R. Eliezer, resulting in his ostracism and the loss of his Torah, as lamented in the lack of disciples and the failure of R. Akiba to learn all that he should have. The Bavli storytellers have thoroughly reworked their source into a completely different story.

\section{The Sources of the Bavli Reworking and the Dating of the Composition}

The questions then become: can we determine the sources of these BT reworkings? And if so, does this help date the composition of the вт story?

(1) R. Eliezer's lament recalling what R. Akiba learned (B2c), lacking in the PT, draws on t. Sanh. 11:5:

out of the room." The more clearly set scene of the вт story accordingly places R. Eliezer in his "canopied bed," presumably in his bedroom, and the Sages in the "receiving room" such that Hyrcanos can really "enter" the bedroom from the receiving room and "leave in disgrace" back to the receiving room, after which the Sages "enter" the bedroom. It is also possible, of course, that the в т storytellers altered the scene to conform to their notions of the realia of the domicile of a leading sage. At all events, the change produces a difficulty with the sequence of the вт account. Because Hyrcanos has left the bedroom to speak with the Sages, R. Eliezer should not respond to him, "Your mind and your mother's mind are confused," as he is no longer in the room. (This forced one commentator to explain that R. Eliezer had an extremely keen sense of hearing such that he could in fact hear from the other room; see Joseph Chaim, Sefer Ben Yehoyada, ad loc., s.v. nikhnesu). Moroever, R. Eliezer does not specify which severe commandment Hyrcanos has neglected; the statement is almost incomprehensible without the Yerushalmi's more detailed explanation. On the other hand, the Bavli simplifies the narrative flow to a certain extent, as we have (1) R. Eliezer's rebuke, (2) Hyrcanos not understanding why he is rebuked and concluding his father is confused, and (3) R. Eliezer explaining the halakhic logic. In the PT, by contrast, we have R. Eliezer explaining the logic first, then Hyrcanos thinking his father is confused, and then R. Eliezer asserting he is not in fact confused. For this reason we must explain that Hyrcanos did not understand his father's explanation, though he heard it. (And perhaps this too bothered the B $\mathrm{T}$ storytellers, who felt that if R. Eliezer explained the halakhic logic, Hyrcanos should have understood it, and therefore deferred the explanation until after the exit.) We have here a nice example of how the вT storytellers' reworking of an earlier tradition produces slight but telling incongruities.

75 Mention of the tefillin returns full circle to the opening scene, Hyrcanos's attempt to remove them, which has a certain aesthetic appeal. It also enhances the theme of sons and disciples: the son could not serve his father appropriately where the disciple successfully performs this service. 
R. Akiba said: R. Eliezer derived 300 interpretations from [the verse], You shall not tolerate a sorceress (Exod 22:17), yet I only learned two things from him: Of two collecting cucumbers [by magical methods] —one collecting is culpable, and the other collecting is exempt. The one who performs a [magical] act is culpable; the one who creates an illusion is exempt. ${ }^{76}$

Here then we have (a) R. Akiba learning from R. Eliezer; (b) 300 laws (halakhot) about magic; (c) R. Akiba only learned two of the 300 ; (d) the two were about cucumbers. To be sure, the вт has transformed this source significantly, such that: (a) in the вт R. Eliezer reports that R. Akiba learned from him as a flashback, whereas in the Tosefta R. Akiba reports what he himself learned from R. Eliezer; (b) the 300 traditions are all about (magical manipulation of) cucumbers, not magic in general. These laws are expounded (doresh) by R. Eliezer, i.e., interpretations of the verse, whereas in the вт they are "taught" (shoneh), apparently in Mishnah-form, not as exegesis, hence the verse is not quoted. The possibility that there were 3000 is added; (c) R. Akiba explicitly asks R. Eliezer to teach him about the cucumbers; (d) R. Eliezer performs a magical act on the cucumbers, rather than teaching a law about those who perform magic, as noted above. The в $\mathrm{T}$ storytellers have liberally reworked the Toseftan source in much the same way they reworked the PT story.

Most importantly, this source helps account for two of the three major BT transformations: (1) the interest in R. Akiba as a disciple of R. Eliezer and the relationship between the two; (2) the loss of Torah, or the failure of R. Eliezer to transmit his Torah. It seems to me that the storytellers extrapolated from the fact that R. Akiba reports of the 300 traditions, "I only learned two things from him" (ולא למדתי הימנו אלא שני דברים) that the other hundreds of traditions were lost, and that the same was true of other dimensions of R. Eliezer's knowledge. Perhaps, too, if the greatest of sages, R. Akiba, only learned two traditions from R. Eliezer, the other Sages learned nothing. ${ }^{77} \mathrm{I}$ am not sure if this tradition completely accounts for the image of R. Eliezer in the story and the theme of the loss of his Torah, which seems to be a larger BT construct, but it provides a partial explanation. I know of no other source (other than the parallels in 'Abot R. Nat. and later midrashim, which derive from the Bavli) that portrays R. Eliezer and his Torah in this way.

76 Cf. m. Sanh. 7:11, cited below.

77 However, see below, "Redactional Context," on the relationship between the story and Mishnah. 
Various Bavli sources mention 300 laws, including Doeg and Ahitofel teaching 300 laws about a "tower flying in the air" (b. Sanh. 106b = b. Hag. 15b), the 300 laws that Joshua forgot after the death of Moses (b. Tem. 16a), and the 300 responses of Yonatan b. Harkinos (b. Yebam. 16a; which also appears in y. Yebam. 1:6, 3a), although I find no other tradition of 300 laws about the bright spot specifically. ${ }^{78}$

(2) The story of the "Oven of Akhnai" as formulated at b. B. Meș. 59a-b played a significant role in the вт's reworking. ${ }^{79}$ This account probably shares responsibility for the prominent role of R. Akiba, as he volunteers to inform R. Eliezer of the ban, which perhaps points to some sort of special relationship between the two sages. ${ }^{80} \mathrm{R}$. Akiba sits at a distance of four cubits, as do the Sages in our story. As noted, the description of R. Yehoshua "standing on his feet" and proclaiming the annulment of the ban seems to quote the description of R. Yehoshua in b. B. Mes. $59 \mathrm{~b}$. Also as noted, the reference to the "shoe on the last" was apparently chosen to evoke t. 'Ed. 2:1, the Toseftan passage that mentions the Oven of Akhnai.

Moreover, the BT's reversal of the PT plot whereby R. Eliezer does not retract may be again a product of incorporating aspects of the Bavli's version of the account of the ban. The PT version of the "Oven of Akhnai" in fact concludes with R. Eliezer observing that eventually the Sages will "bring him near," i.e. annul the ban. The вт version has no such optimistic ending. Rather, R. Eliezer essentially causes the death of Rabban Gamaliel, and the alienation between R. Eliezer and the Sages endures to the end, suggesting that there will be no retraction of his opinion.

(3) That R. Eliezer predicts R. Akiba's death probably devolves from b. Pesah. 69a, where R. Eliezer declares to R. Akiba: "You responded to me with [the law of] slaughtering; by slaughtering you will die." The phrase "yours will be more severe than theirs" may draw on an exegetical tradition attributed to R. Sheila in b. Sanh. 44a, in which God says these same words to Joshua. The BT account may also draw on the well-known traditions of the martyrdom of R. Akiba (b. Ber. 61b; y. Ber. 9:5, 14b), and of other sages in the Roman persecutions following the second revolt. 81

78 See too the parallel Pт sugya to m. Sanh. 7:11, which claims that R. Eliezer actually taught 9oo teachings (parshiot), three sets of 30o, about Exod 22:18.

79 Cf. Steinmetz, "Like Torah Scrolls," 156, 176.

8 o R. Akiba also informs R. Eliezer in the parallel at y. Mo'ed Qat. 3:1, 81c-d.

81 See e.g. b. Git. 57a; y. Ta'an. 4:8, 68d (the death of R. Eleazar of Modiin); y. Sot. 5:7, $20 \mathrm{c}$ (martyrdom of R. Ishmael and R. Shimon). Rabbinic sources generally refer to the "age of persecution," which scholars associate with the aftermath of the Bar Kokhba revolts. 
In b. 'Erub. 63a (= Sipra, Shmini 1:33 [ed. Weiss, p. 45b]), R. Eliezer predicts the imminent death of a student who "teaches the law before his master," and the student dies within a week. Perhaps the predictions of death in our story draw on a more widespread motif of R. Eliezer predicting the death of sages who commit offences. ${ }^{82}$

(4) The image of R. Eliezer's two arms as rolled up Torah scrolls does not really have a parallel elsewhere (B2a). Neusner has suggested that the figure draws on t. Sotahah 15:3: "When R. Eliezer died, the scroll of Torah ${ }^{83}$ was annulled (batel) ... When R. Akiba died the arms (or 'strength'; zero'ei) of Torah was annulled (batel)." ${ }^{\prime 4}$ I.e., when R. Eliezer died a great deal of tradition was lost, as if a Torah scroll is now inaccessible. Thus Rashi, in his comment to the Talmudic citation of this source at b. Soțah 49a (which reads "hidden away" [nignaz] for "annulled"), relates it to our story: "He knew a great many laws from tradition, and they were set in order in his mouth as if written in a scroll, as is said in [Tractate] Sanhedrin, 'I have learned a great amount of Torah from my teachers." $" 85$ The disciples actually call R. Eliezer "the Scroll of Torah" in b. Sanh. 101a, employing this same phrase from t. Sotah 15:3. In this account R. Eliezer becomes sick and his disciples, including R. Akiba, visit him. R. Akiba laughs and the disciples weep, explaining: "Is it possible that Scroll of Torah lies in pain and we not weep"? Perhaps too the description of R. Akiba as the "arms" of Torah in t. Sotah 15:3 relates to the description of R. Eliezer comparing his arms to Torah scrolls. So it is possible we are dealing with a kind of narrativization of these images, though this explanation does not fully satisfy me.

Let me note in passing that this account (b. Sanh. 101a) and the immediately following source also feature R. Akiba and other sages visiting the sick R. Eliezer, and have R. Akiba stand out from among the other sages in that he recites a surprising teaching that occasions a question from R. Eliezer. These accounts too may suggest a special relationship between the two sages.

The similes of the dog lapping from the sea and the painting stick from the tube for a minimal amount of Torah, to the best of my knowledge, are unique here. ${ }^{86}$

82 Cf. b. Hag. 3 b where R. Eliezer, offended by what R. Yose b. Dormasqit reports to him has transpired in the house of study, orders the sage to mutilate himself by removing his eye.

83 MS Vienna of t. Sotah 15:3 reads "the honor of the Torah."

84 Cf. t. Soțah 15:3.

85 Rashi, s.v. nignaz.

86 The figure of the dog lapping at the sea is only found here. That of the painting stick and the tube appears in halakhic contexts related to the consummation of sexual intercourse among both animals and humans. See e.g. b. Mak. 7a; b. B. Meș. 91a. Goshen-Gottstein, 
The general image of R. Eliezer as a sage who served his masters devotedly, repeating that which he heard but not creatively innovating or deriving new inferences, draws on various rabbinic sources, though the Bavli here pushes that image to an extreme. ${ }^{87}$

(5) The violence and hostility of the account is characteristic of Bavli descriptions of hostile interactions between sages, and of its hyperbolic rhetoric in general. 88

(6) The expanded eulogy (C), as far as I can determine, does not draw directly on other traditions.

(7) Finally, many phrases and brief expressions in the story have parallels in other Bavli narratives, such as "That day was the eve of the Sabbath," 89 "He rebuked him and he left (or "dismissed him") in disgrace,"90 "He said to them, 'Why have you come?' They said, 'We have come to learn Torah," "91 "We had no free time,"92 "His blood gushed." ${ }^{93}$ But most of these appear to be stock expressions that do not necessarily point to the storytellers here adapting material from the parallels, as is sometimes found in late Bavli stories.

Elsewhere I have tried to formulate criteria by which to distinguish stories of Amoraic provenance from those that emerge from the Stammaim and betray evidence of Stammaitic reworking. ${ }^{94}$ The reworking in this case appears to be on the borderline. Thematically, there are none of the classic themes of late Stammaitic narratives, such as the highly populated and hierarchically structured academy, dialectics, and academic warfare. From a compositional perspective, the BT storytellers did not transfer other Bavli passages wholesale, using the same words with minor adaptations to fit the new context. While they clearly drew on, and were influenced by, other traditions, for the most part they do not seem to have had access to the redacted sugyot that appear in our вт..$^{95}$

"Lonely Sage," 87 and n. 27, attempts to relate these sexual connotations to aspects of the story.

87 See b. Sukkah 28a, where R. Eliezer declares, "I never spoke a word that I did not receive from my masters”; b. Ḥag. 3a-b; b. Yoma 66b; t. Yebam. 3:1; m. 'Abot 2:8; Gilat, R. Eliezer, 1.

88 See n. 56 .

89 b. Šabb. 31a, b. Šabb. 88a, b. Yoma 35b; y. Kil. 9:3, 32c. Palestinian sources typically use the phrase "the eve of the Sabbath, at dusk" (erev shabbat im hasheikhah), as in the PT parallel here. Cf. m. Šabb. 2:7, m. B. Bat. 5:8.

$90 \quad$ b. Šabb. 31a; Sipre to Deuteronomy \#305 (p. 326).

91 b. Ber. 63 a.

92 b. Mo'ed Qaț. 17b ("they did not have time," in an halakhic, not narrative context); b. Šabb. 88a ("he did not have time").

93 m. 'Ohal. 3:5; b. Sanh. 107a.

94 Stories of the Babylonian Talmud, 217-228.

95 For the stages in the process of redaction of the Bavli, see David Weiss Halivni, Meqorot 
Many of the traditions they employ appear in Tannaitic sources, not exclusively in the BT, and would have been available to Amoraim-considerations that suggest an Amoraic provenance. On the other hand, the dependence on the story on the Bavli's version of "the Oven of Akhnai," which is of Stammaitic provenance, ${ }^{96}$ and perhaps on the tradition of R. Eliezer predicting Akiba's death, as well as a few of the other parallels, point to Stammaitic composition. So too does the high degree of narrative artistry and the extensive reworking of t. Sanh. 11:5. ${ }^{97}$ This suggests that the composition took place in the early Stammaitic period, during the time when the Stammaim were first creating sugyot out of Amoraic traditions, but prior to the period when those early sugyot were fixed in their current locations and later redactors transferred and adapted material directly from one sugya to another. ${ }^{98}$ The Stammaitic period was a lengthy era that included many stages, from the initial composition of sugyot, to the transposition of materials between proto-sugyot, to their redaction in specific contexts in the proto-Talmud, to later editing and transpositions. ${ }^{99}$ The incorporation of so much unparalleled material points to the earlier stages of this era.

\section{Redactional Context}

The story appears in b. Sanh. 68a, the Talmudic commentary to m. Sanh. 7:11, which I juxtapose with t. Sanh. 11:5 and the relevant passage of our story.

umesorot: Bava batra (Jerusalem: Magnes, 2007), 126-127; Jay Rovner, "Pseudepigraphic Invention and Diachronic Stratification in the Stammaitic Component of the Bavli: The Case of Sukka 28," HUCA 68 (1997): 53-61. This is therefore not a case such as that which Shamma Friedman describes wherein the Bavli's expansions of Palestinian aggadot are paralleled in another location in the Bavli "as if that chapter and that sugya lay open before the composer of the gemara" ("La'aggada hahistorit," 139 n. 106).

96 Rubenstein, Talmudic Stories, 53-62; Jay Rovner, "Structure and Ideology in the Aher Narrative," JSIJ 10 (2012): 216 and n. 48.

97 See Jay Rovner, "Rav Assi Had This Old Mother," in Creation and Composition: The Contribution of the Bavli Redactors (Stammaim) to the Aggadah, ed. J.L. Rubenstein (Tübingen: Mohr Siebeck, 2005), 113-114; and idem, "Structure and Ideology in the Aher Narrative," 224-225.

98 See David Weiss Halivni, The Formation of the Babylonian Talmud, trans. Jeffrey L. Rubenstein (New York: Oxford University Press, 2013), xxviii, 156-164.

99 See Halivni, Meqorot umesorot, 9-10; idem, The Formation of the Babylonian Talmud, xxvii$\mathrm{xxx}$. 
$\begin{array}{lll}\text { m. Sanh. } 7: 11^{100} & \text { t. Sanh. 11:5 Sanh. 68a (story) }\end{array}$

R. Akiba said in the name

R. Akiba said: R. Eliezer

[R. Eliezer said ...] "Not of R. Yehoshua:

derived 300 laws from [the verse] You shall not tolerate a sorceress (Exod 22:17), yet I only learned two things from him: only that, but I recite 300 laws - some say 3000 laws - about the planting of cucumbers, and no one ever asked me a question about it, except for Akiba b. Yosef:

Of two collecting cucumbers [by magical methods]_one collecting is exempt, and the other collecting is culpable. The one who performs a [magical] act is culpable; the one who creates an illusion is exempt.
Of two collecting cucumbers [by magical methods]_one collecting is culpable, and the other collecting is exempt. The one who performs a [magical] act is culpable; the one who creates an illusion is exempt.
Once we were walking on our way, and he said to me, 'My master. Teach me one thing about the planting of cucumbers.' I taught him one thing, and the whole field filled up with cucumbers. He said to me, 'My master: You taught me about their planting. Teach me about their uprooting.' I said one thing and they all gathered in one place."

After citing the Mishnah, the Talmud queries: "Did R. Akiba learn this from R. Yehoshua? But did we not learn ...," continues with our story, and then comments, "therefore he learned this from R. Eliezer." Thus this anonymous BT sugya is concerned with a contradiction: the Mishnah reports that R. Yehoshua taught R. Akiba traditions about the magical harvesting of cucumbers, whereas the story relates that R. Eliezer taught R. Akiba those magical traditions. Now this contradiction ultimately devolves from the contradiction between $\mathrm{m}$. Sanh. 7:11 and t. Sanh. 11:5 (which is even more blatant than the contradiction between m. Sanh. 7:11 and the story, since in the Tosefta R. Akiba attributes to R. Eliezer the verbatim laws about magic found in the Mishnah, whereas in the

100 This tradition also appears in Sipre to Deuteronomy \#171 (p. 219). 
story Akiba learns magical acts, though the Bavli evidently did not make this distinction.) Because the storytellers included a reworked version of t. Sanh. 11:5 into their story about R. Eliezer, the same contradiction resulted.

The в т resolves the contradiction by claiming that "he learned (gamra) from R. Eliezer, but did not understand it (savra); then he learned from R. Yehoshua, who explained it (asberah) to him." This solution employs a common Bavli distinction between learning, in the sensing of memorizing, a tradition or law $(g m r)$ and understanding the justification or reasoning behind it (svr). Hence the story is prior to the Mishnah: because R. Akiba did not understand R. Eliezer's pedagogy he ultimately learned these same laws from R. Yehoshua.

On one level, this resolution of the contradiction is extremely ironic in that it eliminates the two traditions R. Eliezer believed he had transmitted. Where R. Eliezer lamented how few sages asked him questions, and how many of his hundreds of traditions would die with him, the Bavli now denies him even the minor solace he took in in the two traditions he communicated to R. Akibain fact he was not successful!101 Yet from a second point of view the resolution is true to the narrative insofar as it claims that R. Eliezer lacked disciples and interlocutors. The вT commentary simply embellishes the degree of his isolation and the extent that he failed to pass on his traditions.

In this way the contextualization enhances a prominent theme of the story. Yet there is a reciprocal impact of the story on the redactional context.

The lengthy sugya that precedes the story contains traditions about the nature of magic, including different categories of magic, almost a rudimentary taxonomy, and claims about how different kinds of magic work. ${ }^{102}$ There are also stories of sages performing magic of various sorts and of magical duels between Amoraim and sorcerers/witches. As noted above, descriptions of Amoraim engaging in magic are routine in both Talmuds. R. Eliezer teaching R. Akiba two magical acts in the story is therefore of one piece with the preceding sugya. Yet both the sugya and the story ostensibly contradict the Mishnah, which expresses the Tannaitic prohibition against engaging in magic. This very problem is raised by the anonymous sugya that follows the story, and follows immediately after the resolution of the contradiction about whom R. Akiba learned from: "How could he [R. Eliezer] do this [magic on the cucumbers]? Did we not learn (in m. Sanh. 7:11), "The one who performs a [magical] act is culpable?" The Talmud's solution is to distinguish learning for the sake of

\footnotetext{
101 See Devora Steinmetz, "Agada Unbound: Inter-Agadic Characterization of Sages in the Bavli and Implications for Reading Agada," in Creation and Composition, 332, n. 85. And see Steinmetz, "Like Torah Scrolls," 170-171 and n. 51.

102 See Levinson, "Enchanting Rabbis," 69-75, for analysis of this sugya.
} 
understanding and teaching, which is permitted, from learning in order to practice magic for its own sake, which is forbidden. And with that the sugya concludes. In this respect the story functions as a coda of sorts to the entire sugya. The question, "How could he do this?," could be said equally of the other Amoraim featuring in the sugya, such as R. Hanina and R. Oshaya, who created a calf ex nihilo and ate it, and R. Yannai, who turned spilled water into snakes. Rashi in fact was so scandalized by R. Yannai's performance that he rejected the reading he received, "Rabbi Yannai," in favor of "Yannai," since "he was not an upright man, as he engaged in magic."103 The actions of these and other Amoraim can be justified on the same grounds, that they learned these techniques to teach and understand and not to perform them for their own sake, as did R. Eliezer (and R. Akiba!). In addition, the story provides a genealogy for magical praxis, a precedent for the Amoraic "magicians" described throughout the Talmudic sugya in the great Tannaim of the story. These and other Amoraim (and later sages studying the sugya, the intended audience) need feel no compunctions about engaging in magic as the tradition of rabbinic magic goes back at least as far as R. Eliezer and R. Akiba, in whose steps they follow.

It is even possible that the redactors attempted to create a segue to the story, to link it more closely to the preceding material. The final tradition of the sugya, which appears immediately before the story is this:

And the frog came up and covered the whole land of Egypt (Exod 8:2). R. Eleazar said: It was one frog and it filled the entire Land of Egypt. This is the matter of a dispute among Tannaim: R. Akiba said: It was one frog and it filled the entire Land of Egypt. R. Eleazar b. Azariah said to him: Akiba! What business do you have with aggadah? Cease your words and go engage in Leprosy (negaim) and Tent-Impurity (ohalot). It was one frog; it croaked for others and they came.

The content of this tradition has little to do with the sugya. It does not focus on magic, nor really with anything that comes beforehand. There is a weak, formal connection to a tradition somewhat earlier in the sugya that quotes Exodus 8:15, Then the magicians said to Pharaoh: 'This is the finger of God,' about the plague of lice, on the basis of which R. Eleazar claims that magicians cannot create creatures less than the size of a barley corn. Here then is another tradi-

103 The same sensibility seems to have led the scribes of the Munich, Florence and Rav Herzog manuscripts to omit "R.," but it is present in the geniza fragment Cambridge T-S F2(1) 169 . 
tion of R. Eleazar (b. Pedat) about the plagues, albeit unrelated to magic, and the Talmud then coordinates it with a Tannaitic dispute. Nevertheless, the tradition seems to be tacked on gratuitously to a coherent and well-focused sugya otherwise devoid of digressions.

I would suggest, with all due caution, that what motivated the redactors to include this tradition was less that it features the same R. Eleazar (b. Pedat) than the associated Tannaitic dispute that mentions R. Akiba and his studies: R. Eleazar b. Azariah rebukes R. Akiba for studying aggadah and directs him to a more appropriate subject, the purity laws of leprosy and tents. There is a certain parallel between this charge that $\mathrm{R}$. Akiba studied the wrong subject and R. Eliezer's rebuke of R. Akiba (and the Sages) for not having studied with him, that they engaged in the wrong type of study, and also the implication that R. Akiba failed to learn what he should have (thus the harshest death. ${ }^{104}$ ) Moreover, according to the anonymous sugya that follows the story, R. Akiba did not even understand what he learned from R. Eliezer, much as R. Eleazar $b$. Azariah suggests he does not understand the workings of aggadah. The mention of leprosy (nega'im) also intersects with the story in that R. Eliezer knows 300 laws of the bright spot, which is one of the signs of leprosy. While the form of this tradition therefore connects to the previous sugya (a dictum attributed to R. Eleazar b. Pedat), the content connects to the story that follows. The student of Talmud, having encountered this tradition, is more prepared for the portrayal of R. Akiba in the story.

Now it should be noted that the BT redactional context differs from that of the PT (y. Šabb. 2:5, 5 b), where the story is redacted in connection to $\mathrm{m}$. Šabb. 2:7. That mishnah lists "Three things that one must state in his house on the eve of the Sabbath at dusk," the third of which is "Light the Sabbath lamp!" and then deals with what to do in cases of doubt as to whether it is still dusk. This law clearly intersects with the first scene of the story, as the setting is "the eve of the Sabbath at dusk," and R. Eliezer rebukes his son for neglecting the pressing concerns at that time. In this context the story serves to reinforce the Mishnah's admonition to light lamps at the appropriate time: even the dying R. Eliezer admonished his son to attend to this task before all others. Indeed, the previous mishnah claims that women die in childbirth as punishment for negligence in this ritual. In the вт the story has been redacted in connection with m. Sanh. 7:11 because of R. Eliezer's reference to the tradition of cucumber planting, which does not appear in the PT, and is a result of the Babylonian reworking that draws on t. Sanh. 11:5.

104 See n. 34. 
Consideration of the в $\mathrm{T}$ redactional context supports the dating of the story to the early Stammaitic period. The redactors of this sugya evidently knew of the completed BT story, which had been composed at some earlier point by reworking the PT tradition. They realized that the story contradicted the Mishnah and therefore integrated it as described above: juxtaposing the story with the Mishnah, resolving the contradiction, and adding the follow-up question and answer. If the analysis above has merit, they also created a bridge to the story by including the tradition with R. Akiba's exegesis of Exodus 8:2. There is no evidence that these redactors contributed to the composition of the story, as we sometimes find, ${ }^{105}$ by reworking it so as to connect it to the material with which it is contextualized. Rather, they included the story not only to resolve the contradiction with m. Sanh. 7:11, but because the depiction of R. Eliezer relates to the content of the previous sugya.

\section{Appendix: Manuscript Variants}

Only major variants are listed here: Munich $95=$ M; Jerusalem, Yad Harav Her$\mathrm{zog}=\mathrm{He}$; Florence $9=\mathrm{F}^{2}$; Karlsruhe $($ Reuchlin 2$)=\mathrm{K}$. (These manuscript abbreviations are from Michael Sokoloff, A Dictionary ofJewish Babylonian Aramaic [Ramat-Gan: Bar Ilan University Press; Baltimore: The Johns Hopkins University Press, 2002], 58.) Orthographic variants are not listed. Additional variants can be found in R.N. Rabbinowicz, Diqduqei sofrim, reprint, 12 vols. (New York, 1960), 9:192-194.

(A3) "His mind and his mother's mind." $\mathrm{He}, \mathrm{F}^{2}$, K read: "Your mind and your mother's mind."

(B1c) "'What about my [death]?' He said to him, 'Yours will be more severe than theirs." He, $\mathrm{F}^{2}$ read: "his [death] ... His will be ..."

(B2a) "even as much (afilu) as a dog": $\mathrm{F}^{2}$, K omit: "even as much."

(B2b) "bright spot." K reads: "bright as snow."

(B2c) "I said one thing, and the whole field filled up with cucumbers." K, F read: "I taught one thing, and ..."

(B3) "They [the Sages] said to him: 'Master:" He omits "Master."

(B3a) "They are made pure [by immersion] as they are" (bameh shehen). He, $\mathrm{K}, \mathrm{F}^{2}$ read: "They become pure by any amount" (bemashehu). (This would seem to be an error in light of the Tannaitic parallels.)

105 See Rubenstein, Talmudic Stories, 255-267; idem, Stories of the Babylonian Talmud, 207217 . 
(B3c) "And his soul departed with 'Pure." He adds: "A heavenly voice went forth and said: Happy are you, R. Eliezer the Great, that your body is pure and your soul departed with 'Pure."

(Bia) "We have come to learn Torah." $\mathrm{F}^{2}$ omits "We have come."

(C) "In the row (shura)." $\mathrm{F}^{2}$ reads "in song" (or "with his eulogy"; shira).

\section{Bibliography}

Baitner, Azaria. Yavneh Stories [in Hebrew]. Ramat Gan: Bar-Ilan University Press, 2011. Beek, M.A. "The Meaning of the Expression 'The Chariots and the Horsemen of Israel' (2 Kings ii 12)." In The Witness of Tradition: Papers Read at the Joint British-Dutch Old Testament Conference Held at Woudschoten, 1970. Edited by M.A. Beek, 1-10. Leiden: Brill, 1972.

Bohak, Gideon. Ancient Jewish Magic: A History. Cambridge: Cambridge University Press, 2008.

Boyarin, Daniel. Border Lines: The Partition ofJudaeo-Christianity. Philadelphia: University of Pennsylvania Press, 2004.

Boyarin, Daniel. Dying for God. Stanford: Stanford University Press, 1999.

Calderon, Ruth. "Literary Tropes in the Aggadic Narratives of the Babylonian Talmud" [in Hebrew]. Ph.D. dissertation, Jerusalem, Hebrew University, 2006.

Delehaye, Hippolyte. The Legends of the Saints: An Introduction to Hagiography. Translated by V.M. Crawford. London: Longmans, Green and Co., 1907.

Fisch, Menachem. Rational Rabbis: Science and Talmudic Culture. Indiana: Bloomington: Indiana University Press, 1997.

Fraenkel, Yonah. "Hermeneutical Questions in the Study of the Aggadic Narrative" [in Hebrew]. Tarbiz 47 (1978): 157-161.

Fraenkel, Yonah. "Time and Its Shaping in Aggadic Narratives" [in Hebrew]. In Studies in Aggadah, Targum and Jewish Liturgy in Memory of Joseph Heinemann. Edited by J.J. Petuchowski and E. Fleischer, 147-152. Jerusalem: Magnes, 1981.

Friedman, Shamma. "La'aggada hahistorit batalmud habavli." In Saul Lieberman Memorial Volume. Edited by Shamma Friedman, 119-163. New York: Jewish Theological Seminary, 1993.

Friedman, Shamma. "Now You See It, Now You Don't: Can Source-Criticism Perform Magic on Talmudic Passages about Sorcery?" In Rabbinic Traditions between Palestine and Babylonia. Edited by R. Nikolsky and T. Ilan, 43-61. Leiden: Brill, 2014.

Gilat, Y. R. Eliezer ben Hyrcanus: A Scholar Outcast. Translated by E.J. Frank. Ramat Gan: Bar-Ilan University Press, 1984.

Goshen-Gottstein, Alon. "A Lonely Sage on His Death-Bed: The Story of Rabbi Eli'ezer (Sanhedrin 68a), an Ideological Analysis" [in Hebrew]. In Mehkarim batalmud 
uvamidrash:Seferzikkaron letirzah lifshitz. Edited by Moshe Bar-Asher, Joshua Levinson, and Berachyahu Lifshitz, 79-112. Jerusalem: Bialik, 2005.

Halivni, David Weiss. The Formation of the Babylonian Talmud. Translated by Jeffrey L. Rubenstein. New York: Oxford University Press, 2013.

Halivni, David Weiss. Meqorot umesorot: Bava batra. Jerusalem: Magnes, 2007.

Hayyim b. Elijah al-Hakham, Joseph. Sefer Ben Yehoyada. Edited by Yeshua b. David Salim. 7 vols. Jerusalem, 1998.

Jastrow, Marcus. A Dictionary of the Targumim, the Talmud Babli and Yerushalmi and the Midrashic Literature. New York, 1893. Reprint New York:Judaica, 1989.

Levinson, Joshua. "Boundaries and Witches: Stories of Conflicts between Rabbis and Magicians in Rabbinic Literature" [in Hebrew]. Tarbiz 75 (2006): 295-328.

Levinson, Joshua. "Enchanting Rabbis: Contest Narratives between Rabbis and Magicians in Late Antiquity." JQR 100 (2010): 54-94.

Levy, Jacob. Wörterbuch über die Talmudim und Midraschim. 4 vols. Berlin: B. Harz, 1924.

Naeh, Shlomo. "On Structures of Memory (and the Forms of Text) in Rabbinic Literature" [in Hebrew]. In Mehqerei Talmud 3. Edited by Y. Sussman and D. Rosenthal, 543-589. Jerusalem: Magnes, 199 o.

Neusner, Jacob. Eliezer ben Hyrcanus: The Tradition and the Man. 2 vols. Leiden: Brill, 1973.

Rabbinowicz, R.N. Diqduqei sofrim. Reprint. 12 vols. New York, 196o.

Raveh, Inbar. Me'at meharbeh. Or Yehudah: Devir, 2008.

Rovner, Jay. "Pseudepigraphic Invention and Diachronic Stratification in the Stammaitic Component of the Bavli: The Case of Sukka 28." HUCA 68 (1997): 53-61.

Rovner, Jay. "Rav Assi Had This Old Mother." In Creation and Composition: The Contribution of the Bavli Redactors (Stammaim) to the Aggadah. Edited by J.L. Rubenstein, 101-124. Tübingen: Mohr Siebeck, 2005.

Rovner, Jay. "Structure and Ideology in the Aher Narrative." JSIJ 10 (2012): 183-255.

Rubenstein, Jeffrey L. The Culture of the Babylonian Talmud. Baltimore, MD: Johns Hopkins University Press, 2003.

Rubenstein, Jeffrey L. Stories of the Babylonian Talmud. Baltimore, MD: Johns Hopkins University Press, 2010.

Rubenstein, Jeffrey L. Talmudic Stories: Narrative Art, Composition, and Culture. Baltimore, MD: Johns Hopkins University Press, 1999.

Saldarini, Anthony J. “Last Words and Deathbed Scenes in Rabbinic Literature." JQR 68 (1977): 28-45.

Sokoloff, Michael. A Dictionary ofJewish Babylonian Aramaic. Ramat-Gan: Bar Ilan University Press; Baltimore: The Johns Hopkins University Press, 2002.

Steinmetz, Devora. "Agada Unbound: Inter-Agadic Characterization of Sages in the Bavli and Implications for Reading Agada." In Creation and Composition: The Contri- 
bution of the Bavli Redactors (Stammaim) to the Aggadah. Edited by J.L. Rubenstein, 293-338. Tübingen: Mohr Siebeck, 2005.

Steinmetz, Devora. “'Like Torah Scrolls That Are Rolled Up': The Story of the Death of Rabbi Eliezer in Sanhedrin 68a." In Tiferet Leyisrael:Jubilee Volume in Honor of Israel Francus. Edited by J. Roth, M. Schmelzer, and Y. Francus, 153-179. New York: Jewish Theological Seminary, 2010.

Stratton, Kimberley. "Imagining Power: Magic, Miracle, and the Social Context of Rabbinic Self-Representation." JAAR 73 (2005): 361-393.

Stratton, Kimberley. Naming the Witch: Magic, Ideology, and Stereotype in the Ancient World. New York: Columbia University Press, 2007.

Zlotnick, Dov. The Tractate “Mourning.” New Haven: Yale University Press, 1966. 